\title{
The Role of Biochar in Regulating the Carbon, Phosphorus, and Nitrogen Cycles Exemplified by Soil Systems
}

\author{
Shu-Yuan Pan ${ }^{1} \mathbb{1}$, Cheng-Di Dong ${ }^{2, *} \mathbb{1}$, Jenn-Fang Su ${ }^{3}$, Po-Yen Wang ${ }^{4}$, Chiu-Wen Chen ${ }^{2}$, Jo-Shu Chang ${ }^{5,6}$, \\ Hyunook Kim ${ }^{7}$, Chin-Pao Huang ${ }^{8}$ and Chang-Mao Hung ${ }^{2}$ \\ 1 Department of Bioenvironmental Systems Engineering, National Taiwan University, \\ Taipei City 10617, Taiwan; sypan@ntu.edu.tw \\ 2 Department of Marine Environmental Engineering, National Kaohsiung University of Science and \\ Technology, Kaohsiung City 811213, Taiwan; cwchen@nkust.edu.tw (C.-W.C.); \\ hungcm@nkust.edu.tw (C.-M.H.) \\ 3 Department of Chemical and Materials Engineering, Tamkang University, New Taipei City 251301, Taiwan; \\ jennfangsu@mail.tku.edu.tw \\ 4 Department of Civil Engineering, Widener University, Chester, PA 19013, USA; pwang1@widener.edu \\ 5 Department of Chemical and Materials Engineering, College of Engineering, Tunghai University, \\ Taichung City 407224, Taiwan; changjs@mail.ncku.edu.tw \\ 6 Department of Chemical Engineering, National Cheng Kung University, Tainan City 701, Taiwan \\ 7 School of Environmental Engineering, University of Seoul, Seoul 02504, Korea; h_kim@uos.ac.kr \\ 8 Department of Civil and Environmental Engineering, University of Delaware, Newark, DE 19716, USA; \\ huang@udel.edu \\ * Correspondence: cddong@nkust.edu.tw
}

check for

updates

Citation: Pan, S.-Y.; Dong, C.-D.; Su, J.-F.; Wang, P.-Y.; Chen, C.-W.; Chang, J.-S.; Kim, H.; Huang, C.-P.; Hung, C.-M. The Role of Biochar in Regulating the Carbon, Phosphorus, and Nitrogen Cycles Exemplified by Soil Systems. Sustainability 2021, 13, 5612. https://doi.org/10.3390/ su13105612

Academic Editor: Gabrijel Ondrasek

Received: 25 March 2021

Accepted: 11 May 2021

Published: 18 May 2021

Publisher's Note: MDPI stays neutral with regard to jurisdictional claims in published maps and institutional affiliations.

Copyright: (c) 2021 by the authors. Licensee MDPI, Basel, Switzerland. This article is an open access article distributed under the terms and conditions of the Creative Commons Attribution (CC BY) license (https:// creativecommons.org/licenses/by/ $4.0 /)$.

\begin{abstract}
Biochar is a carbon-rich material prepared from the pyrolysis of biomass under various conditions. Recently, biochar drew great attention due to its promising potential in climate change mitigation, soil amendment, and environmental control. Obviously, biochar can be a beneficial soil amendment in several ways including preventing nutrients loss due to leaching, increasing $\mathrm{N}$ and $\mathrm{P}$ mineralization, and enabling the microbial mediation of $\mathrm{N}_{2} \mathrm{O}$ and $\mathrm{CO}_{2}$ emissions. However, there are also conflicting reports on biochar effects, such as water logging and weathering induced change of surface properties that ultimately affects microbial growth and soil fertility. Despite the voluminous reports on soil and biochar properties, few studies have systematically addressed the effects of biochar on the sequestration of carbon, nitrogen, and phosphorus in soils. Information on microbially-mediated transformation of carbon $(\mathrm{C})$, nitrogen $(\mathrm{N})$, and phosphorus $(\mathrm{P})$ species in the soil environment remains relatively uncertain. A systematic documentation of how biochar influences the fate and transport of carbon, phosphorus, and nitrogen in soil is crucial to promoting biochar applications toward environmental sustainability. This report first provides an overview on the adsorption of carbon, phosphorus, and nitrogen species on biochar, particularly in soil systems. Then, the biochar-mediated transformation of organic species, and the transport of carbon, nitrogen, and phosphorus in soil systems are discussed. This review also reports on the weathering process of biochar and implications in the soil environment. Lastly, the current knowledge gaps and priority research directions for the biochar-amended systems in the future are assessed. This review focuses on literatures published in the past decade (2009-2021) on the adsorption, degradation, transport, weathering, and transformation of C, N, and P species in soil systems with respect to biochar applications.
\end{abstract}

Keywords: biochar; carbon; nitrogen; phosphorus; adsorption; degradation; transport; weathering

\section{Introduction}

Soil, an important carbon sink that is also the largest terrestrial carbon pool, plays a critical role in regulating the global carbon cycle. Minasny et al. (2017) estimated that 4\% 
of the top $1 \mathrm{~m}$ of agricultural soils can hold 2-3 $\mathrm{Gt} \mathrm{CO}_{2}$ annually, representing a 20-35\% offset of global anthropogenic greenhouse gas emissions [1].

Biochar has gained considerable attention in its role in regulating the natural carbon cycle in biogeochemical systems such as soils, as an environmentally friendly adsorbent for $\mathrm{CO}_{2}$. Woolf et al. (2010) estimated that biochar removed 1.0-1.8 $\mathrm{Gt} \mathrm{CO}_{2}-\mathrm{C}$ equivalent of greenhouse gases from the atmosphere annually (Figure 1) [2]. Additionally, as a soil amendment, biochar can improve soil fertility [3] and crop yields [4]. Other benefits of biochar applications can be realized by nutrients management practices $[5,6]$.

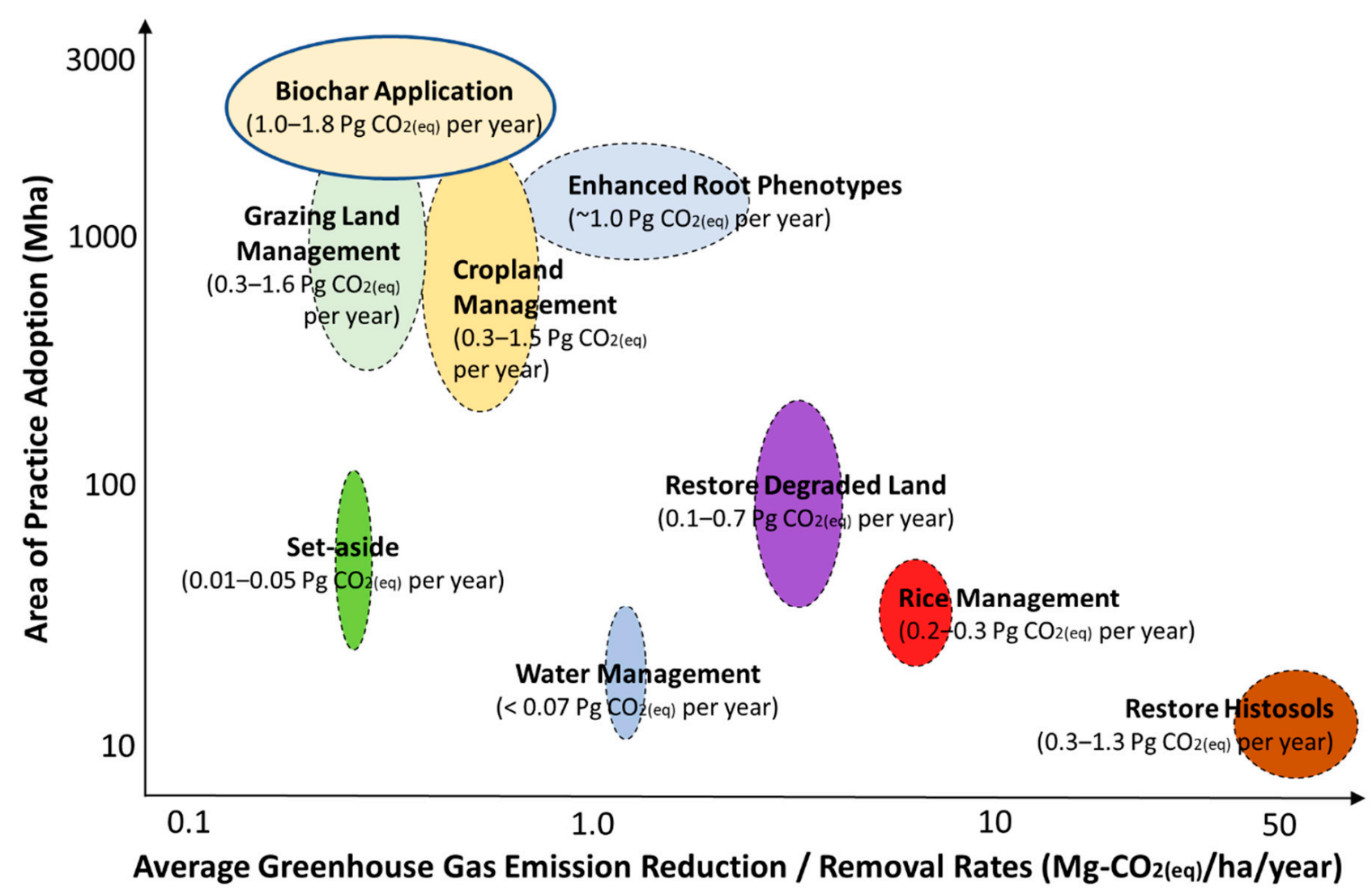

Figure 1. Global potential for agricultural-based greenhouse gas mitigation practices, where biochar application considers a global mitigation potential of 1.0-1.8 Gt CO $2-C$ equivalent per year. Adapted from Paustian et al. (2016) [7].

Nitrogen $(\mathrm{N})$ is an essential nutrient for plant growth and productivity. The loss of $\mathrm{N}$ in the environment, through leaching, volatilization, and denitrification, potentially increases inorganic anions, such as nitrate $\left(\mathrm{NO}_{3}{ }^{-}\right)$in groundwater, and raises greenhouse gas (GHG, e.g., $\mathrm{N}_{2} \mathrm{O}$ ) emissions [8-12]. Biochar as a soil amendment can modify soil physical chemical properties, stimulate microbial activities, increase nutrient availability, and impact plant productivity [13-19]. Moreover, the massive production of agricultural wastes worldwide provides abundant sources for biochar preparation, which makes biochar a readily available, environmentally friendly, and cost-effective soil conditioner [20]. 
Similar to nitrogen, phosphorus is a sustaining and growth-limiting nutrient for plant growth. Phosphorus is immobile in soils once it is applied as fertilizer to crops growth because of adsorption, precipitation, and biological assimilation into organic species. Surface runoffs tend to wash off phosphorus and nitrogen to surface water and ultimately cause eutrophication of the receiving water bodies [21]. The incorporation of biochar in soils is one of the effective measures to minimize release of phosphorus and nitrogen nutrients from soils for water quality protection [22-24]. Arif et al. (2017) reported that the application of biochar significantly increased crop yields, soil organic carbon, and available nitrogen and phosphorus nutrients [23].

Obviously, biochar can be a beneficial soil amendment, such as (i) decreasing nutrients' leaching loss, (ii) increasing $\mathrm{N}$ and $\mathrm{P}$ mineralization, and (iii) enabling microbial mediation of $\mathrm{N}_{2} \mathrm{O}$ and $\mathrm{CO}_{2}$ emissions $[15,25,26]$. However, there are also conflicting reports on biochar effects. Specifically, factors, such as the source materials and procedures for the preparation of biochar that might affect the surface properties for biochar with respect to nutrients retention and utilization, and long-term effects of biochar applications on soil ecosystems, are not yet thoroughly explored. Therefore, strategies to improve biochar use and efficacy are needed. Despite the voluminous reports on soil and biochar properties, few studies have systematically addressed the effects of biochar on the sequestration of carbon, nitrogen, and phosphorus in soils. Information on microbially-mediated transformation of carbon $(\mathrm{C})$, nitrogen $(\mathrm{N})$, and phosphorus $(\mathrm{P})$ species in the soil environment remains relatively uncertain. This review focuses on literatures published in the past decade (20092021) on the adsorption, degradation, transport, weathering, and transformation of $C, N$, and $\mathrm{P}$ species in soil systems with respect to biochar applications.

\section{Adsorption of Carbon, Nitrogen, and Phosphorus Species}

Table 1 summarizes the molecular composition and physical properties of biochar generated from various feedstocks. The biochar yield, hydrogen content $(\mathrm{H} \%)$, and oxygen content $(\mathrm{O} \%)$ typically decreased with an increasing pyrolysis temperature [27-29]. On the other hand, the carbon content $(\mathrm{C} \%), \mathrm{pH}$, and surface area usually increased with elevated pyrolysis temperatures $[18,28]$. Additionally, the pore volume of biochars also increased with an increase in a specific surface area, suggesting that the pore size distribution may be another important factor responsible for the increase in the surface area of biochar $[27,29]$. $\mathrm{N} \%$ in biochar usually was dependent on the type of feedstock, and thus no significant trend of pyrolysis temperature on $\mathrm{N} \%$ of biochar was observed. The element $\mathrm{C}, \mathrm{H}, \mathrm{O}$, and $\mathrm{N}$ are common building blocks of biochar. Pyrolysis condition has a significant influence on the characteristics of the fundamental building blocks, resulting in the diversity of biochar [30-37]. 
Table 1. Characteristics of biochars produced from different feedstocks and their adsorption capacity.

\begin{tabular}{|c|c|c|c|c|c|c|c|c|c|c|c|c|}
\hline Feedstock & $\begin{array}{l}\text { Pyrolysis } \\
\text { Temp. }\left({ }^{\circ} \mathrm{C}\right)\end{array}$ & Yield (\%) & $\mathrm{pH}$ & $\mathrm{C}(\%)$ & H (\%) & $\mathrm{O}(\%)$ & N (\%) & $\begin{array}{l}\text { BET Surface } \\
\text { Area }\left(\mathrm{m}^{2} \mathrm{~g}^{-1}\right)\end{array}$ & $\begin{array}{l}\text { Pore Volume } \\
\quad\left(\mathrm{cm}^{3} \mathrm{~g}^{-1}\right)\end{array}$ & Adsorbate & $\begin{array}{l}\text { Adsorption Capacity } \\
\left(\mathrm{mg} \mathrm{g-Biochar}^{-1}\right)\end{array}$ & References \\
\hline \multirow{23}{*}{ Pine needles } & \multirow{3}{*}{100} & \multirow{3}{*}{91.2} & \multirow{3}{*}{-} & \multirow{3}{*}{50.9} & \multirow{3}{*}{6.15} & \multirow{3}{*}{42.3} & \multirow{3}{*}{0.71} & \multirow{3}{*}{0.7} & \multirow{3}{*}{-} & naphthalene & 0 & \multirow{23}{*}{ [27] } \\
\hline & & & & & & & & & & nitrobenzene & 0 & \\
\hline & & & & & & & & & & m-dinitrobenzene & 0 & \\
\hline & \multirow{3}{*}{200} & \multirow{3}{*}{75.3} & \multirow{3}{*}{-} & \multirow{3}{*}{57.1} & \multirow{3}{*}{5.71} & \multirow{3}{*}{36.3} & \multirow{3}{*}{0.88} & \multirow{3}{*}{6.2} & \multirow{3}{*}{-} & naphthalene & 0.329 & \\
\hline & & & & & & & & & & nitrobenzene & 5.908 & \\
\hline & & & & & & & & & & m-dinitrobenzene & 5.655 & \\
\hline & \multirow{3}{*}{250} & \multirow{3}{*}{56.1} & \multirow{3}{*}{-} & \multirow{3}{*}{61.2} & \multirow{3}{*}{5.54} & \multirow{3}{*}{32.4} & \multirow{3}{*}{0.86} & \multirow{3}{*}{9.5} & \multirow{3}{*}{-} & naphthalene & 1.724 & \\
\hline & & & & & & & & & & nitrobenzene & 10.08 & \\
\hline & & & & & & & & & & m-dinitrobenzene & 7.535 & \\
\hline & \multirow{3}{*}{300} & & & & & & & & & naphthalene & 4.006 & \\
\hline & & 48.6 & - & 68.9 & 4.31 & 25.8 & 1.08 & 19.9 & - & nitrobenzene & 51.14 & \\
\hline & & & & & & & & & & m-dinitrobenzene & 17.09 & \\
\hline & & & & & & & & & & naphthalene & 25.69 & \\
\hline & 400 & 30.0 & - & 77.9 & 2.95 & 18.0 & 1.16 & 112.4 & 0.044 & nitrobenzene & 79.71 & \\
\hline & & & & & & & & & & naphthalene & 27.40 & \\
\hline & 500 & 26.1 & - & 81.7 & 2.26 & 15.0 & 1.11 & 236.4 & 0.095 & nitrobenzene & 96.63 & \\
\hline & & & & & & & & & & m-dinitrobenzene & 55.23 & \\
\hline & & & & & & & & & & naphthalene & 15.14 & \\
\hline & 600 & 20.4 & - & 85.4 & 1.85 & 11.8 & 0.98 & 206.7 & 0.076 & nitrobenzene & 91.99 & \\
\hline & & & & & & & & & & m-dinitrobenzene & 35.83 & \\
\hline & & & & & & & & & & naphthalene & 136.8 & \\
\hline & 700 & 14.0 & - & 86.5 & 1.28 & 11.1 & 1.13 & 490.8 & 0.186 & nitrobenzene & 181.2 & \\
\hline & & & & & & & & & & m-dinitrobenzene & 208.0 & \\
\hline
\end{tabular}


Table 1. Cont.

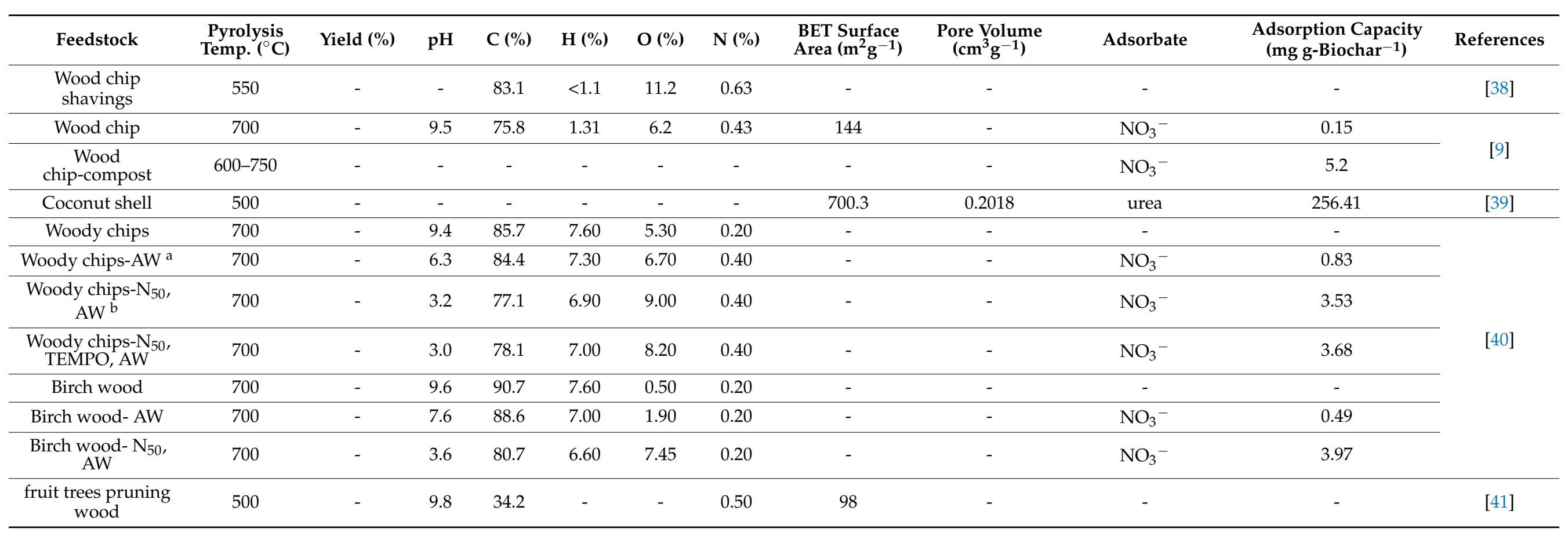


Table 1. Cont

\begin{tabular}{|c|c|c|c|c|c|c|c|c|c|c|c|c|}
\hline Feedstock & $\begin{array}{l}\text { Pyrolysis } \\
\text { Temp. }\left({ }^{\circ} \mathrm{C}\right)\end{array}$ & Yield (\%) & $\mathrm{pH}$ & $\mathrm{C}(\%)$ & H (\%) & $\mathrm{O}(\%)$ & N (\%) & $\begin{array}{l}\text { BET Surface } \\
\text { Area }\left(\mathrm{m}^{2} \mathrm{~g}^{-1}\right)\end{array}$ & $\begin{array}{l}\text { Pore Volume } \\
\left(\mathrm{cm}^{3} \mathrm{~g}^{-1}\right)\end{array}$ & Adsorbate & $\begin{array}{l}\text { Adsorption Capacity } \\
\left.\text { (mg g-Biochar }{ }^{-1}\right)\end{array}$ & References \\
\hline Biosolids-DBS ${ }^{\mathrm{c}}$ & - & - & - & 37.3 & - & - & 48.2 & - & - & terbuthylazine & $K_{d}=2.56 \mathrm{~L} / \mathrm{kg}^{\mathrm{g}}$ & \multirow{4}{*}{ [42] } \\
\hline Biosolids-UBS $^{d}$ & - & - & - & 6.42 & - & - & 5.13 & - & - & terbuthylazine & $K_{d}=3.22 \mathrm{~L} / \mathrm{kg}$ & \\
\hline Charcoal & 350 & - & - & 83.4 & - & - & 0.21 & - & - & terbuthylazine & $K_{d}=6.69 \mathrm{~L} / \mathrm{kg}$ & \\
\hline Sawdust & 700 & - & - & 89.4 & - & - & 0.17 & - & - & terbuthylazine & $K_{d}=115.6 \mathrm{~L} / \mathrm{kg}$ & \\
\hline Oak sawdust & 300 & 76.17 & 6.8 & 50.2 & 5.78 & 41.6 & 0.27 & - & - & $\mathrm{NH}_{4}^{+}$ & 5.31 & [28] \\
\hline Oak sawdust & 500 & 24.90 & 8.3 & 76.5 & 3.42 & 16.6 & 0.39 & - & - & - & - & [28] \\
\hline Oak sawdust & 600 & 21.60 & 8.4 & 80.4 & 3.12 & 12.2 & 0.43 & - & - & $\mathrm{NO}_{3}{ }^{-}$ & 8.94 & [28] \\
\hline $\begin{array}{c}\text { Oak } \\
\text { sawdust-LaCl } \\
\end{array}$ & 300 & 73.07 & 5.4 & 40.3 & 5.48 & 40.2 & 0.28 & - & - & $\mathrm{NH}_{4}^{+}$ & 10.10 & [28] \\
\hline $\begin{array}{c}\text { Oak } \\
\text { sawdust-LaCl } \\
\end{array}$ & 500 & 30.50 & 7.8 & 69.8 & 3.37 & 23.2 & 0.46 & - & - & - & - & [28] \\
\hline $\begin{array}{c}\text { Oak } \\
\text { sawdust- } \mathrm{LaCl}_{3}\end{array}$ & 600 & 29.13 & 7.9 & 75.7 & 2.64 & 17.6 & 0.48 & - & - & $\mathrm{NO}_{3}{ }^{-}$ & 100.0 & [28] \\
\hline \multirow{4}{*}{ Lignin } & RT & - & - & 43.7 & 4.50 & 31.1 & 0.12 & 2.01 & 0.00624 & $\mathrm{NO}_{3}{ }^{-}$ & 0.189 & \multirow{5}{*}{ [43] } \\
\hline & 350 & - & - & 62.6 & 3.27 & 22.5 & 0.16 & 0.710 & 0.00292 & $\mathrm{NO}_{3}{ }^{-}$ & 0.408 & \\
\hline & 500 & - & - & 72.1 & 2.03 & 14.9 & 0.26 & 208 & 0.0855 & $\mathrm{NO}_{3}{ }^{-}$ & 0.505 & \\
\hline & 700 & - & - & 63.8 & 0.91 & 19.8 & 0.42 & 201 & 0.0976 & $\mathrm{NO}_{3}^{-}$ & 0.785 & \\
\hline Lignin-TA $^{\mathrm{e}}$ & 500 & - & - & 85.8 & 2.45 & 9.30 & 0.39 & 3.65 & 0.00595 & $\mathrm{NO}_{3}{ }^{-}$ & 0.357 & \\
\hline
\end{tabular}


Table 1. Cont.

\begin{tabular}{|c|c|c|c|c|c|c|c|c|c|c|c|c|}
\hline Feedstock & $\begin{array}{l}\text { Pyrolysis } \\
\text { Temp. }\left({ }^{\circ} \mathrm{C}\right)\end{array}$ & Yield (\%) & $\mathrm{pH}$ & $\mathrm{C}(\%)$ & H (\%) & $\mathrm{O}(\%)$ & N (\%) & $\begin{array}{l}\text { BET Surface } \\
\text { Area }\left(\mathrm{m}^{2} \mathrm{~g}^{-1}\right)\end{array}$ & $\begin{array}{c}\text { Pore Volume } \\
\left(\mathrm{cm}^{3} \mathrm{~g}^{-1}\right)\end{array}$ & Adsorbate & $\begin{array}{l}\text { Adsorption Capacity } \\
\left(\mathrm{mg} \mathrm{g} \text {-Biochar }^{-1}\right)\end{array}$ & References \\
\hline \multirow{6}{*}{ Sugarcane bagasse } & \multirow{2}{*}{300} & \multirow{2}{*}{-} & \multirow{2}{*}{7.2} & \multirow{2}{*}{69.5} & \multirow{2}{*}{4.20} & \multirow{2}{*}{24.5} & \multirow{2}{*}{0.90} & \multirow{2}{*}{5.2} & \multirow[t]{2}{*}{ - } & $\mathrm{NH}_{4}^{+}$ & $0.175 \% \mathrm{~h}$ & \\
\hline & & & & & & & & & & $\mathrm{NO}_{3}^{-}$ & $-0.361 \%$ & \\
\hline & \multirow{2}{*}{450} & \multirow{2}{*}{-} & \multirow{2}{*}{7.9} & \multirow{2}{*}{78.6} & \multirow{2}{*}{3.5} & \multirow{2}{*}{15.5} & \multirow{2}{*}{0.9} & \multirow{2}{*}{15.3} & \multirow{2}{*}{ - } & $\mathrm{NH}_{4}{ }^{+}$ & $-0.100 \%$ & \\
\hline & & & & & & & & & & $\mathrm{NO}_{3}{ }^{-}$ & $-0.585 \%$ & \\
\hline & \multirow{2}{*}{600} & \multirow{2}{*}{-} & \multirow{2}{*}{7.9} & \multirow{2}{*}{76.5} & \multirow{2}{*}{2.9} & \multirow{2}{*}{18.3} & \multirow{2}{*}{0.8} & \multirow{2}{*}{4.2} & \multirow{2}{*}{-} & $\mathrm{NH}_{4}{ }^{+}$ & $0.090 \%$ & \\
\hline & & & & & & & & & & $\mathrm{NO}_{3}{ }^{-}$ & $0.636 \%$ & \\
\hline \multirow{7}{*}{ Peanut hull } & 300 & - & 78 & 739 & 39 & 191 & 16 & 08 & - & $\mathrm{NH}_{4}{ }^{+}$ & $0.550 \%$ & \\
\hline & 300 & 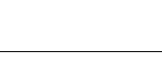 & 1.0 & 13.9 & 3.9 & 19.1 & 1.0 & 0.8 & 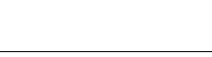 & $\mathrm{NO}_{3}{ }^{-}$ & $-0.619 \%$ & \\
\hline & 450 & - & 82 & 815 & 29 & 130 & 10 & 218 & - & $\mathrm{NH}_{4}{ }^{+}$ & $-1.00 \%$ & \\
\hline & 700 & 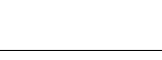 & 0.2 & 01.3 & 2.9 & 10.0 & 1.0 & 21.0 & 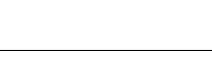 & $\mathrm{NO}_{3}^{-}$ & $-0.430 \%$ & \\
\hline & 600 & - & 80 & 86.4 & 14 & 10.0 & 0.9 & 271 & - & $\mathrm{NH}_{4}^{+}$ & $0.500 \%$ & \\
\hline & & & 0.0 & 00.7 & 1.7 & 10.0 & 0.0 & 27.1 & & $\mathrm{NO}_{3}^{-}$ & $0.0344 \%$ & \\
\hline & $300(\mathrm{HT})^{\mathrm{f}}$ & - & 68 & 564 & 56 & 367 & 09 & 56 & - & $\mathrm{NH}_{4}{ }^{+}$ & $-0.15 \%$ & {$[44]$} \\
\hline & 300 & - & 66 & 593 & 52 & 34.1 & 03 & 811 & - & $\mathrm{NH}_{4}^{+}$ & $0.190 \%$ & \\
\hline & 300 & & 0.0 & 39.3 & 0.2 & 34.1 & 0.3 & 81.1 & & $\mathrm{NO}_{3}{ }^{-}$ & $-0.722 \%$ & \\
\hline Brazilian & 450 & - & 7.3 & 75.6 & 3.6 & 17.2 & 0.3 & 0.7 & - & $\mathrm{NH}_{4}^{+}$ & $0.785 \%$ & \\
\hline pepperwood & 450 & 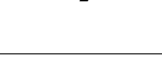 & 7.3 & 75.6 & 3.6 & $1 / .2$ & 0.3 & 0.7 & 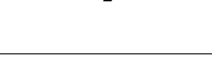 & $\mathrm{NO}_{3}{ }^{-}$ & $-0.791 \%$ & \\
\hline & 600 & - & 91 & 770 & 22 & 177 & 01 & 2347 & - & $\mathrm{NH}_{4}{ }^{+}$ & $0.595 \%$ & \\
\hline & 600 & 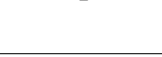 & 9.1 & 77.0 & 2.2 & $1 / .7$ & 0.1 & 234.7 & 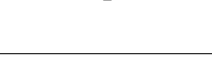 & $\mathrm{NO}_{3}{ }^{-}$ & $0.0206 \%$ & \\
\hline & 300 & - & 67 & 66.2 & 47 & 277 & 0.4 & 13 & - & $\mathrm{NH}_{4}^{+}$ & $0.200 \%$ & \\
\hline & & & 0.7 & 00.2 & $\mathrm{x} . \mathrm{r}$ & $2 \pi .7$ & $0 . x^{2}$ & 1.0 & 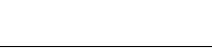 & $\mathrm{NO}_{3}^{-}$ & $-0.224 \%$ & \\
\hline Bamboo & 450 & - & 52 & 769 & 36 & 181 & 02 & 182 & - & $\mathrm{NH}_{4}{ }^{+}$ & $-0.650 \%$ & \\
\hline Dantus & 400 & 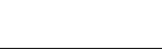 & 0.2 & 10.9 & 0.0 & 10.1 & 0.2 & 18.2 & 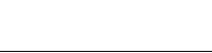 & $\mathrm{NO}_{3}{ }^{-}$ & $-0.344 \%$ & \\
\hline & 600 & - & 79 & 809 & 24 & 149 & ? & 4704 & - & $\mathrm{NH}_{4}{ }^{+}$ & $0.200 \%$ & \\
\hline & 000 & & 7.9 & 00.9 & 2.4 & 14.9 & 0.2 & $4 / 0.4$ & & $\mathrm{NO}_{3}{ }^{-}$ & $0.430 \%$ & \\
\hline
\end{tabular}


Table 1. Cont.

\begin{tabular}{|c|c|c|c|c|c|c|c|c|c|c|c|c|}
\hline Feedstock & $\begin{array}{l}\text { Pyrolysis } \\
\text { Temp. }\left({ }^{\circ} \mathrm{C}\right)\end{array}$ & Yield (\%) & $\mathrm{pH}$ & C (\%) & H (\%) & $\mathrm{O}(\%)$ & N (\%) & $\begin{array}{l}\text { BET Surface } \\
\text { Area }\left(\mathrm{m}^{2} \mathrm{~g}^{-1}\right)\end{array}$ & $\begin{array}{l}\text { Pore Volume } \\
\left(\mathrm{cm}^{3} \mathrm{~g}^{-1}\right)\end{array}$ & Adsorbate & $\begin{array}{l}\text { Adsorption Capacity } \\
(\mathrm{mg} \mathrm{g} \text {-Biochar } \\
\end{array}$ & References \\
\hline \multirow{6}{*}{ Corn straw } & 100 & - & - & 47.5 & 6.23 & 0.36 & 46.0 & 2.14 & - & simazine & $K_{d}=124 \mathrm{~L} / \mathrm{kg}$ & \multirow{6}{*}{ [45] } \\
\hline & 200 & - & - & 53.8 & 5.71 & 0.66 & 39.9 & 2.15 & - & simazine & $K_{d}=574 \mathrm{~L} / \mathrm{kg}$ & \\
\hline & 300 & - & - & 66.9 & 4.14 & 1.24 & 27.7 & 6.14 & - & simazine & $K_{d}=2669 \mathrm{~L} / \mathrm{kg}$ & \\
\hline & 400 & - & - & 76.5 & 3.99 & 1.27 & 18.2 & 32.4 & 0.003 & simazine & $K_{d}=1618 \mathrm{~L} / \mathrm{kg}$ & \\
\hline & 500 & - & - & 82.0 & 3.36 & 1.03 & 13.6 & 245.3 & 0.0345 & simazine & $K_{d}=3133 \mathrm{~L} / \mathrm{kg}$ & \\
\hline & 600 & - & - & 84.3 & 2.60 & 1.16 & 12.0 & 329.0 & 0.0839 & simazine & $K_{d}=4054 \mathrm{~L} / \mathrm{kg}$ & \\
\hline
\end{tabular}

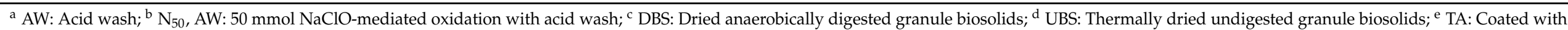
tannic acid; ${ }^{\mathrm{f}}$ HT: Hydrothermal carbonization; ${ }^{\mathrm{g}} K_{d}$ : Adsorption distribution coefficient; ${ }^{\mathrm{h}}$ removal rate (\%). 
Biochar has received great attention in environmental remediation due to its adsorption capacity for pollutants including heavy metals, dyes, pharmaceuticals, and persistent organic pollutants [46-49]. Additionally, biochar application affects $\mathrm{N}$ and $\mathrm{P}$ transport in soils and regulates fertilizer release because of its remarkable sorption capacity (Table 1) $[14,39,50,51]$. Several surface properties including specific surface area, functional groups, and surface charge are major factors affecting the adsorption capacity of biochar.

A larger specific surface area is generally related to better sorption capacity due to abundant active sites [52]. Bargmann et al. (2014) studied the ammonium sorption capacity of biochar and hydrochar (made from the same feedstocks, i.e., beet-root chips and spent brewer's grains) and reported that biochar amendment increased $\mathrm{NH}_{4}{ }^{+}-\mathrm{N}$ adsorption in soils, attributed to its ten times larger specific surface area than hydrochar [53]. Yang et al. (2017) studied nitrate adsorption on a series of biochar prepared from different feedstocks and at different pyrolysis temperatures and reported a nitrate adsorption capacity in the range of 0.03 to $0.78 \mathrm{mg} \mathrm{NO}_{3}{ }^{-}-\mathrm{N} / \mathrm{g}$, and that the increase in $\mathrm{NO}_{3}{ }^{-}$adsorption capacity was attributed to the higher temperature and feedstocks having a higher lignin content [29] (Table 1). Although the specific surface area appeared to be the major factor controlling nitrogen adsorption in both studies, the relationship between the specific surface area and $\mathrm{NO}_{3}{ }^{-}$adsorption was only weakly correlated $\left(R^{2}=0.57, p<0.05\right)$, suggesting that the specific surface area was not always a dominant factor.

The biochar surface may contain aliphatic, aromatic, hydroxyl, epoxy, carboxyl, acyl, carbonyl, ether, ester, amido, sulfonic, and azyl groups, among which phenolic-OH, carboxyl, carbonyl, and ester groups are particularly abundant [54]. The Brönsted acid-base nature of the above surface functional groups is the origin of hydrogen bonding $[9,19,55-57]$, $\mathrm{pH}$ buffer intensity [58], hydrophobicity, and cation exchange capacity (CEC) [59]. The functional groups on the biochar surface are sites responsible for adsorption and surface modification. Wang et al. (2015) added lanthanum chloride $\left(\mathrm{LaCl}_{3}\right)$ to the biomass during the pyrolysis process, so as to increase the $\mathrm{O} / \mathrm{C}$ and $(\mathrm{O}+\mathrm{N}) / \mathrm{C}$ ratio $($ Table 1$)$, which consequently produced oxygen-containing functional groups on the La-biochar surface, and significantly improved $\mathrm{NO}_{3}{ }^{-}$and $\mathrm{NH}_{4}{ }^{+}$adsorption [28].

The electrostatic interactions between the biochar surface and charged species in soils was previously suggested as the most common adsorption mechanism [9,40,59-61]. Surface functional groups are primary origins of surface charge, which is highly related to $\mathrm{pH}$ in the aqueous phase. In most cases, the surface of biochar is negatively charged; the surface turns to positive only under acidic conditions, e.g., $\mathrm{pH}<\mathrm{pH}_{\text {zpc }}$ [62]. 


\subsection{Adsorption of Carbon Species}

\subsubsection{Inorganic Carbons}

The use of boichar as a soil amendment could improve the $\mathrm{CO}_{2}$ sequestration potential in the agro-ecosystems system. Woolf et al. (2010) found that biochar amendment in soil exhibited a larger mitigation potential (by means of $\mathrm{CO}_{2}$ sequestration) than combustion of the same biomass as bioenergy [2] (Figure 2). The maximum mitigation potential for biochar amendment and the conversion of biomass to bioenergy was ca. $12 \%$ and $10 \%$ of the current anthropogenic $\mathrm{CO}_{2}$-C equivalent emissions, respectively [2]. Soil $\mathrm{CO}_{2}$ sequestration by biochar applications could be mainly attributed to adsorptive and reactive removals of organic and/or inorganic carbons. The mechanisms of adsorptive removal for organic $\mathrm{CO}_{2}$ by biochar include electrostatic force, hydrogen-bonds' interaction, pore filling, hydrophobic sorption, and $\pi-\pi$ (electron donors and acceptors) interaction. The dominant adsorption mechanisms would depend on a number of factors, including the properties of biochar (mainly functional groups on the surface of biochar), the species of carbon in soils, and the physico-chemical-biological properties of amended soils. The content of soil organic carbon has been considered as an essential indicator of soil quality and plant productivity, as it ameliorates the soil's physico-chemical and biological properties.

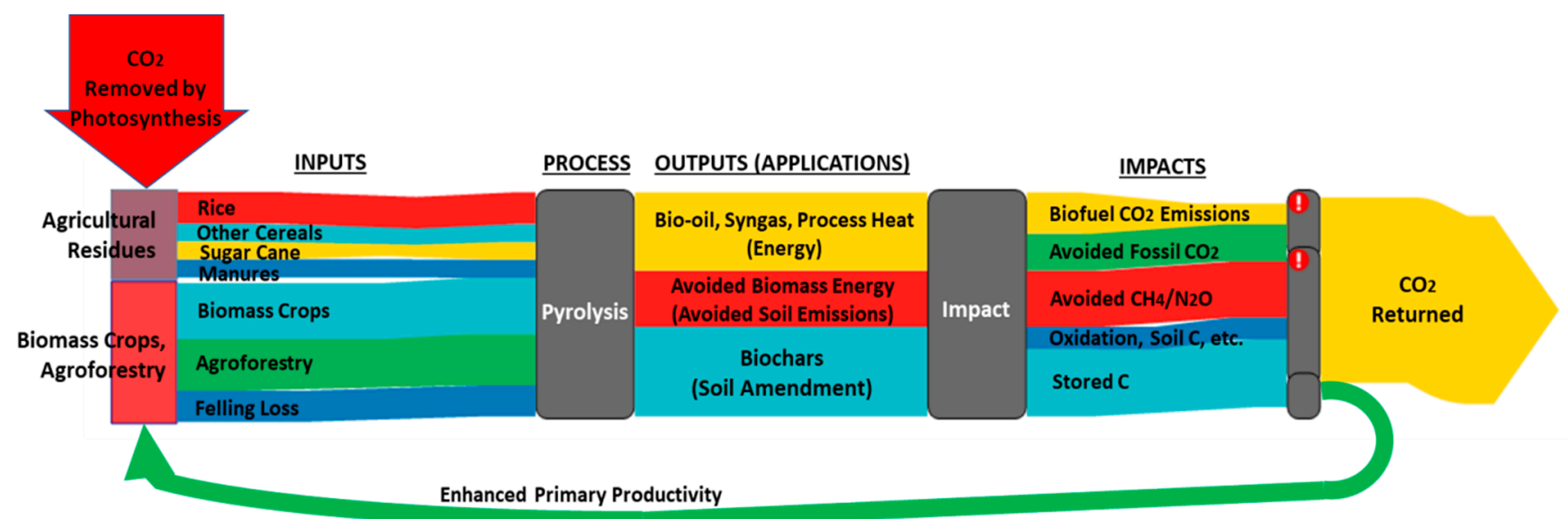

Figure 2. Contribution of sustainable biochar for mitigating global climate change. The results of the analysis indicated that biochar amendment in soil exhibited a larger mitigation potential than combustion of the same biomass as bioenergy, except when fertile soils are amended while coal is the fuel being offset. Adapted from Woolf et al. (2010) [2].

In some cases, the increase in $\mathrm{CO}_{2}$ fluxes into the air might be attributed to the fraction of labile carbon in biochar that could be metabolized by microorganisms (a bio-weathering process), and thus result in higher microbial activity and subsequent $\mathrm{CO}_{2}$ emissions [63]. Little information is available on the effect of biochar on soil inorganic carbon in long-term field operations. Luo et al. (2016) reported that soil biochar amendment would accelerate the conversion of soil organic carbon to inorganic carbon [64]. The increase in soil organic carbon mineralization was $1.71,0.32$, and $0.17 \%$, for a biochar to soil ratio of $0.1,1$, and $3 \%$ respectively. 
Most studies demonstrated that the application of biochar in soils enhanced $\mathrm{CO}_{2}$ sequestration in the soil while boosting crop growth and yield $[4,65]$. In order to estimate the potential of the soil $\mathrm{CO}_{2}$ sequestration capacity with biochar amendment, it is essential to establish indicators, in terms of core biotic and abiotic properties that control soil carbon contents at different spatial scales. Note that the source and type of feedstock would play an important role in affecting the intrinsic properties of biochar, such as temperature sensitivity [66], thereby affecting the soil carbon sequestration potential of biochar. The performance of biochar for $\mathrm{CO}_{2}$ sequestration in soils would also greatly depend on the operating parameters of manufacturing processes, including pyrolysis (e.g., temperature) as well as subsequent modification and/or functionalization processes. Jung et al. (2019) summarized the physico-chemical properties of biochar produced from a lignocellulosic biomass and the $\mathrm{CO}_{2}$ adsorption capability as affected by operating factors of manufacturing processes [67]. Similarly, Rittl et al. (2018) reported that biochar of a low $\mathrm{C} / \mathrm{N}$ ratio (e.g., 20-30) exhibited a higher environmental health risk by increasing soil carbon emissions (loss) than that of a high $\mathrm{C} / \mathrm{N}$ ratio (e.g., >100) [68].

Soil properties also affect long-term $\mathrm{CO}_{2}$ sequestration capacity. Wu et al. (2016) reported that paddy soils with low organic carbon content were suitable for $\mathrm{CO}_{2}$ sequestration by biochar on a long-term basis [69]. Other geo-environmental parameters, including climate [70], topography [71], soil microorganisms [72,73], and soil management practices such as tillage, irrigation, and fertilization [74], also affected the content of soil carbon. Namoi et al. (2019) suggested that the presence of earthworms in biochar-amended soils at a loading of 25 tonne/ha suppressed greenhouse gases emissions (e.g., $\mathrm{N}_{2} \mathrm{O}$ ) [75]. Wiesmeier et al. (2019) demonstrated that general topographic parameters, namely, the topographic wetness index, affected $\mathrm{CO}_{2}$ sequestration on a much smaller (e.g., regional) than larger (e.g., sub-continental) scale of applications [76].

\subsubsection{Organic Carbons}

It is noted that the sorption capacity of organic carbon by biochar is attributed to the partition into the non-carbonized and carbonized (adsorption onto) fraction. In general, biochar amendment in soils exhibited significant additive effects on soil organic carbon over a relatively long period of time. The increase in organic carbon content due to biochar amendment would also provide additional benefits to the soil system, such as a decrease in soil erosion potential [77]. Table 2 shows that with biochar amendment, the soil organic carbon contents could be improved by at least $23 \%$, and even up to $698 \%$. The total organic carbon and its labile fractions increased with the increase in biochar loadings [78], thereby improving the microbial activities and $\mathrm{CO}_{2}$ sequestration in the soil. 
Table 2. Effect of biochar amendment in soils on the contents of soil carbon.

\begin{tabular}{|c|c|c|c|c|c|c|c|c|c|c|c|c|c|c|c|c|c|}
\hline \multirow{2}{*}{ Biochar Source } & \multicolumn{4}{|c|}{ Property of Soil a } & \multicolumn{5}{|c|}{ Property of Biochar ${ }^{b}$} & \multicolumn{7}{|c|}{ Performance of Carbon Sequestration ${ }^{c}$} & \multirow{2}{*}{ Reference } \\
\hline & $\mathrm{pH}$ & CEC & TIC & TOC & $\mathrm{pH}$ & CEC & TIC & TOC & $d_{\mathrm{p}}$ & $L$ & $\mathbf{t}$ & $\mathrm{SOC}_{0}$ & $\mathrm{SOC}_{L}$ & $\mathrm{SIC}_{0}$ & $\mathrm{SIC}_{L}$ & $\eta$ & \\
\hline Forest shrub & 4.6 & 6.4 & - & 16 & 9.3 & 72 & - & 700 & - & 40 & 2.5 & $1.81 \pm 0.01$ & $4.99 \pm 0.01$ & - & - & 175 & [79] \\
\hline Wood residue & 5.5 & - & - & 34 & 9.3 & 9 & - & 550 & - & 10 & 2 & $3.45-3.86$ & $4.61-4.86$ & - & - & 41 & [80] \\
\hline Wood residue & 4.8 & 3.6 & - & 4.1 & - & - & - & 815 & - & $4 \%$ & 0.5 & 4.1 & 32.7 & - & - & 698 & [81] \\
\hline Wood residue & 5.2 & 17.8 & - & 15.3 & - & - & - & 815 & - & $4 \%$ & 0.5 & 15.3 & 46.2 & - & - & 202 & [81] \\
\hline Wheat straw & 7.9 & - & - & 15.2 & 11.6 & - & - & 484 & $0-1$ & $5 \%$ & 1.8 & $\sim 15.2$ & $\sim 41.0$ & - & - & 170 & [82] \\
\hline Wheat straw & 8.1 & 22.1 & - & 10.3 & 10.4 & 21.8 & - & 465 & $<0.25$ & 3 & 3 & $12.79 \pm 0.21$ & $17.49 \pm 0.43$ & - & - & 37 & [77] \\
\hline Wheat straw & 5.1 & 8.0 & - & 17.5 & 9.3 & 28.6 & - & 418 & - & 48 & 4 & $17.6 \pm 0.1$ & $28.4 \pm 0.4$ & - & - & 61 & [83] \\
\hline Wheat straw & 4.5 & 15.2 & - & 9.5 & 10.4 & 21.7 & - & 467 & - & 40 & 5 & $8.80 \pm 0.02$ & $13.31 \pm 0.11$ & - & - & 51 & [84] \\
\hline Wheat straw & 8.0 & 10 & - & 4.3 & 10.6 & 12.5 & - & 491 & - & 30 & 5 & 4.32 & 6.96 & - & - & 61 & [85] \\
\hline Wheat straw & 8.1 & 22.1 & - & 10.3 & 10.4 & 21.8 & - & 465 & - & 30 & 3 & $10.32 \pm 0.09$ & $13.71 \pm 0.23$ & - & - & 33 & [77] \\
\hline $\begin{array}{l}\text { Wheat straw \& } \\
\text { peanut shell }\end{array}$ & 7.0 & - & - & 12.4 & 10.2 & - & - & - & $0.3-2$ & 8 & 2 & - & 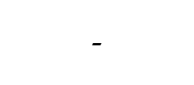 & - & - & $56^{*}$ & [72] \\
\hline Rape straw & 6.7 & - & - & 10.0 & 8.9 & - & - & 626 & 10 & 5.3 & - & $11.82 \pm 0.47$ & $20.76 \pm 0.89$ & - & - & 76 & [86] \\
\hline Maize straw & 5.7 & - & - & 16.0 & 9.4 & - & - & 507 & - & 6.3 & 5 & 17.71 & 21.86 & - & - & 23 & [87] \\
\hline Rice straw & 6.0 & 10.9 & - & 16.6 & 9.2 & 18.9 & - & 620 & - & 9 & 2 & $\sim 24$ & $\sim 36$ & - & - & 50 & [88] \\
\hline Rice straw & 5.2 & 11.3 & - & 21.8 & 10.4 & 19.4 & - & 725 & - & 11.3 & 5 & $45.1 \pm 0.4$ & $126.0 \pm 0.2$ & - & - & 179 & [6] \\
\hline Rice husks & 6.9 & 5.7 & - & 11.0 & 9.2 & 17.6 & - & 478 & - & $3 \%$ & 0.8 & $1.10 \pm 0.03$ & $1.87 \pm 0.04$ & - & - & 70 & [90] \\
\hline Rice husks & 5.8 & 31.5 & - & 4.6 & 9.2 & - & - & 491 & - & $4 \%$ & 0.25 & 0.26 & 0.63 & - & - & 142 & [91] \\
\hline $\begin{array}{l}\text { Rice husks \& } \\
\text { cotton seed }\end{array}$ & 8.0 & 10 & 2.1 & 4.3 & 10.6 & 12.5 & 10.0 & 491 & $0.5-5$ & 90 & 5 & - & - & 0.62 & 0.79 & 27 & [92] \\
\hline Corn cob & 6.0 & - & - & 12.3 & 9.8 & - & - & 803 & - & 40 & 0.13 & $\sim 14$ & $\sim 18$ & - & - & 29 & [93] \\
\hline Corn cob & 7.9 & - & - & 8.2 & 9.6 & - & - & 572 & - & 100 & 0.64 & $8.23 \pm 0.25$ & $24.00 \pm 0.26$ & - & - & 192 & [94] \\
\hline Corn stover & 5.4 & - & - & 34 & 10.0 & 24 & - & 480 & - & 10 & 2 & $3.70-3.86$ & $6.65-4.21$ & - & - & 80 & [80] \\
\hline Bamboo leaf & 4.5 & - & - & 18.6 & 9.4 & - & - & 667 & - & 15 & 1 & $\sim 0.15$ & $\sim 0.19$ & - & - & 27 & [95] \\
\hline Bluestem grass & 7.8 & - & - & 6.2 & 9.7 & - & - & 500 & - & $10 \%$ & 3.5 & - & $5.50 \pm 0.28$ & - & - & 39 & [96] \\
\hline Bluestem grass & 7.7 & - & - & 5.8 & 9.7 & - & - & 500 & - & $10 \%$ & 3.5 & - & $5.70 \pm 0.23$ & - & - & 99 & [96] \\
\hline Sweetgrass & 4.9 & - & - & 16 & 10.8 & 19 & - & 550 & - & 10 & 2 & $2.24-2.34$ & $3.64-5.41$ & - & - & 131 & [80] \\
\hline Pig manure & 4.9 & - & - & - & 8.6 & - & - & 474 & - & $2 \%$ & 0.13 & 0.062 & 0.108 & - & - & 74 & [97] \\
\hline
\end{tabular}

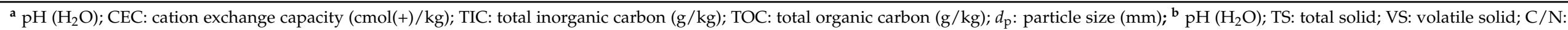

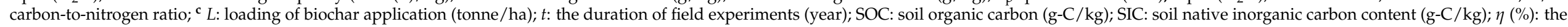
percentage of improvement increase in soil carbon contents; * indicates the efficiency of total carbon increase. 


\subsection{Adsorption of Nitrogen Species}

\subsubsection{Inorganic Nitrogen}

$\mathrm{NH}_{4}{ }^{+}$adsorption was usually attributed to the increase in soil CEC following biochar amendment $[17,60,98,99]$. Most biochar is negatively charged at an ambient $\mathrm{pH}$ so that cationic $\mathrm{NH}_{4}{ }^{+}$can be easily adsorbed via electrostatic attraction. Previous studies reported inconsistent changes in $\mathrm{NO}_{3}{ }^{-}$retention in biochar-amended soils. Yao et al. (2012) studied the adsorption of $\mathrm{NH}_{4}{ }^{+}$and $\mathrm{NO}_{3}{ }^{-}$on 13 different biochar samples in aqueous solutions and reported that adsorption of nitrogen nutrients was highly dependent on the nutrients per sec and type of biochar [44]. Only four of 13 biochar samples prepared at a high pyrolysis temperature $\left(600{ }^{\circ} \mathrm{C}\right)$ exhibited significant $\mathrm{NO}_{3}{ }^{-}$adsorption. On the other hand, nine of 13 biochar samples exhibited $\mathrm{NH}_{4}{ }^{+}$adsorption, likely due to the net negative surface charge. Haider et al. (2016) conducted a long-term field study on nitrate adsorption on silty sand amended by woody chip biochar and observed elevated $\mathrm{NO}_{3}{ }^{-}$concentrations in the topsoil $(0-15 \mathrm{~cm})$ over four-year period, indicating a reduced nitrate leaching by biochar amendment [38]. However, the increase in $\mathrm{N}$ availability did not produce high crop yield. Results clearly indicated that the effects of biochar on crop growth was dependent on crop species, soil type, and biochar properties. Biochar amendment inhibited maize growth due to a decrease in Mn concentrations and an increase in alkalinity in the biocharamended soils; Mn deficiency decreased photosynthetic oxygen evolution by more than $50 \%$ [38]. Ventura et al. (2013) reported a significant decrease in $\mathrm{NO}_{3}{ }^{-}$leaching of $75 \%$ in an apple orchard treated with biochar [41]. Cationic mineral ions such as $\mathrm{Ca}^{2+}, \mathrm{Mg}^{2+}, \mathrm{Al}^{3+}$, and $\mathrm{Fe}^{3+}$ increased $\mathrm{NO}_{3}{ }^{-}$retention in the system because of the bridging effect between $\mathrm{NO}_{3}{ }^{-}$and the soil-biochar mass $[41,100]$. Interestingly, the decrease in $\mathrm{NO}_{3}{ }^{-}$leaching only occurred in the second year after biochar amendment, which suggested the aging effect of biochar applications [41]. The oxidation of the biochar surface, interaction with soil particles, or increase in adsorption sites from particle fragmentation over time appeared to promote nitrate adsorption capacity [41]. Co-composting biochar also enhanced $\mathrm{NO}_{3}{ }^{-}$ capture $[9,61]$ due to two possible mechanisms: (1) unconventional water-ion hydrogenbonding to the nanopores in the biochar and (2) electrostatic bonding with organo-mineral complexes on the co-composted biochar surface $[9,55,61]$. The bonding of water to the nanopore surface in biochar took place through the electron-donation from the $\pi$-clouds in the organic constituents of biochar towards the electron-deficient hydrogens in water. This water-biochar interaction may further lead to weakened unconventional hydrogen-bonding between asymmetrically shaped hydrated nitrate ions and the biochar surface [9,55]. Joseph et al. (2018) reported that high-temperature composting of biochar led to the formation of a porous organo-mineral layer comprised of quinones, positively charged minerals such as $\mathrm{Fe}^{2+}$ and $\mathrm{Fe}^{3+}$, and large macromolecules (humic-like substances) on the biochar surface, which provided positive sites for $\mathrm{NO}_{3}{ }^{-}$binding through electrostatic attraction [61].

Sanford et al. (2019) investigated the effect of chemical treatment on $\mathrm{NO}_{3}{ }^{-}$adsorption characteristics in eight biochar samples by sodium hypochlorite $(\mathrm{NaClO})$ treatment and reported that chemical oxidation of biochar increased the total acid group content, thereby increasing $\mathrm{NO}_{3}{ }^{-}$adsorption [40]. However, this compares to a sorption capacity of $5.2 \mathrm{mg}-\mathrm{NO}_{3}{ }^{-} / \mathrm{g}$ on co-composting biochar reported by Kammann et al. (2015) [9]. Sanford et al. (2019) only observed $3.7 \mathrm{mg}-\mathrm{NO}_{3}{ }^{-} / \mathrm{g}$ on the chemically oxidized biochar [40]. Note that both Kammann et al. (2015) and Sanford et al. (2019) used exactly the same kind of biochar in their studies $[9,40]$, so the difference in sorption capacity clearly indicated that other mechanisms, such as formation of organic coatings, occurred in the co-composting system and might be responsible for nitrate adsorption $[61,101]$. 


\subsubsection{Organic Nitrogen}

Biochar amendment played an important role in the retention and transport of organic nitrogen species in soils because of strong adsorption behavior (Table 1). Pillai et al. (2014) studied the extraction of urea from human urine, affected by factors including initial urea concentration, contact time, biochar loading, and shaking speed via the Response Surface Methodology (RSM) using microwave-activated biochar (developed from coconut shell) in a batch adsorption system [39]. Initial urea concentration and biochar loading were more significant parameters on urea adsorption than contact time and degree of mixing. Pillai et al. (2014) also field-studied plant growth in the presence of urea-laden biochar and reported a remarkable increase in plant biomass [39]. Wang et al. (2009) studied the soil sorption of terbuthylazine enhanced by biochar, as a means to reduce herbicide leaching to the groundwater, and demonstrated that biochar-amended soils exhibited superior sorption performance for terbuthylazine than other soils amended by thermally dried anaerobically digested and undigested granule biosolids [42]. Specifically, a biochar prepared from sawdust at a high pyrolysis temperature $\left(700^{\circ} \mathrm{C}\right)$ exhibited orders of magnitude of a higher adsorption distribution coefficient $\left(K_{d}\right)$ than untreated soils $(115.6 \mathrm{~L} / \mathrm{kg}$ vs. $1.8 \mathrm{~L} / \mathrm{kg})$. Results indicated that the type of organic amendment and pyrolysis temperature affected nitrate adsorption capacity; furthermore, the increase in surface area and porosity in biochar enhanced nitrate adsorption [42,45].

\subsection{Adsorption of Phosphorus Species}

\subsubsection{Inorganic Phosphorus}

The mineral composition significantly governs phosphorus adsorption on biochar due to possible precipitation and direct phosphorus sorption on the biochar surface. The adsorption of phosphorus species on the biochar surface was an endothermic non-spontaneous process. Biochar prepared at a high temperature (greater than $400^{\circ} \mathrm{C}$ ) could be used to neutralize soil acidity [102]. However, under a low $\mathrm{pH}$ condition, biochar-derived dissolved organic matter (DOM) inhibited the adsorption of phosphate [103]. Under an acidic environment, biochar adsorption of phosphate took place by surface complex formation [104]. The Langmuir adsorption isotherm better described phosphorus adsorption on biochar than the Freundlich adsorption isotherm model, which indicated simple stoichiometry sorption on active binding sites [105-107]. The adsorption kinetics followed two distinct stages: rapid chemisorption on positively charged surface sites followed by a surface-diffusion controlled stage when the surface sites were occupied completely [108]. Negatively charged surface functional groups, such as phenolic, hydroxylic, or multi-dentate carboxylic, were adsorption sites for cations [100,109].

In biochar-soil mixtures, the negatively charged biochar would bind common multivalent cations of clay minerals or soil organic matters, such as $\mathrm{Ca}^{2+}, \mathrm{Mg}^{2+}, \mathrm{Al}^{3+}$, and $\mathrm{Fe}^{3+}$, which could be potential adsorption sites for anions. Results of an ATR-FTIR analysis showed that calcium carbonate was a main adsorption site for phosphorus of Mallee biochar, which represented a $16 \%$ increase in phosphorus adsorption and more than $50 \%$ of which were accessible to plant uptake in Mallee biochar $(5 \% w / w)$ conditioned soils [108]. Surface activation by chemicals, such as metal salts, alkali, and nano-particles, significantly enhanced the phosphorus adsorption capacity of biochar [105,106,110-112]. Phosphate adsorption capacity increased from $2.1 \%$ of untreated to $70.3 \%$ of magnesium treated Oak biochar [106]. Magnesiumalginate treatment of biochar exhibited a phosphate adsorption capacity of $46.56 \mathrm{mg} / \mathrm{g}$ [105]. Aluminum (Al) modified biochar showed a phosphorous adsorption capacity in the range from 356 to $701 \mathrm{mg}$ of $\mathrm{P}^{-\mathrm{g}^{-1}}$ of biochar [111]. Results on phosphorus removal from secondary wastewater effluents by biochar loaded with colloidal and nano-sized aluminum oxyhydroxide crystalline flakes showed that, in less than $8 \mathrm{~h}$, $8.3 \mathrm{~g}$ of phosphorus was adsorbed per $\mathrm{kg}$ of engineered biochar in a fixed-bed column [112]. Loading biochar with magnetic nano-particles increased phosphate adsorption capacity by 20-fold compared to that of nano-magnetite [110]. Furthermore, the pyrolysis of poultry litter biomass with phosphate, phosphoric acid, and magnesium oxide strongly decreased 
dissolved phosphorus concentrations due to the strong adsorption and slow-release of phosphate in soils, which facilitated the phosphorus utilization rate [113]. The adsorption capacity increased with the pyrolysis temperature due to the formation of a larger specific surface area [107]. Mia et al. (2017) reported that biochar properties changed with age and phosphate adsorption capacity. The oxidation of oxonium and pyridine groups of fresh biochar decreased the phosphate adsorption capacity. However, aging biochar markedly adsorbed phosphate due to the formation of derivative organic matters on the surface [114], which demonstrated chemisorption as the major mechanism of phosphate adsorption on biochar.

Factors affecting the release of phosphorus species from biochar to soils have also been examined extensively. It was observed that the release of phosphorus species from biochar in both water and neutral soils occurred at a slower and steadier rate over a longer time period than from raw feedstock $[102,115,116]$. The availability of biocharbonded phosphorus species changed under abiotic environmental conditions and was affected by parameters such as $\mathrm{pH}$, temperature, and the concentration of co-existing cations/anions. For instance, low $\mathrm{pH}$, high temperature, or the presence of co-existing anions facilitated the release of biochar-adsorbed phosphorus species. In contrast, high $\mathrm{pH}$, low temperature, or the presence of co-existing cations inhibited the dissolution of bonded phosphorus species [115,117]. Depending on the level of soil phosphorus content, biochar could alternate the phosphorus cycle by increasing the total soil phosphorus concentration from 8.5 to $18 \%$ [116]. The activity of alkaline phosphates in manure biochar-amended soils doubled when soil $\mathrm{pH}$ was raised from 5.2 to 5.8 , thereby increasing available phosphorus for crops [118]. In a column leaching test, up to $93 \%$ of total phosphorus was released from biochar, which indicated the role of ash content in regulating the dissolution of phosphorus species [102]. Maize biochar with different carbonization processes $\left(400\right.$ and $\left.600{ }^{\circ} \mathrm{C}\right)$ increased alkaline phosphatase activity by 3.1- to 4.4-fold after $90 \mathrm{~d}$ [119]. There was a loss of plant available (soluble) phosphorus content due to ortho-phosphate crystallization with insoluble metal salts at higher pyrolysis temperatures. Biochar processed under a low (less than $450^{\circ} \mathrm{C}$ ) to mid (between 450 and $600^{\circ} \mathrm{C}$ ) carbonization temperature significantly improved phosphorus availability in soils [21]. Jian et al. (2019) reported that biochar prepared at $400{ }^{\circ} \mathrm{C}$ released more phosphate than that prepared at $700^{\circ} \mathrm{C}$ into soils [120].

\subsubsection{Organic Phosphorus}

Agro-organophosphorus pesticides, such as chlorpyrifos, fenitrothion, malathion, parathion, and phosphmidon are toxic and can be retained in soils by forming stable complexes with metal oxides [121]. The sorption of organophosphorus pesticides by different types of biochar has been studied [122-125]. The presence of biochar impacted the partition of organophosphorus pesticides that controlled the distribution of pesticides in soil, groundwater, and biochar. Biochar prepared from Gossypium spp. straw chips at $850^{\circ} \mathrm{C}$ effectively reduced the uptake of chlorpyrifos by plants that resulted in high biomass production [124]. Tang et al. also reported that the uptake of chlorpyrifos and its degradation product, 3,5,6-trichloro-2-pyridinol (TCP), by Allium fistulosum L., decreased from $769.23 \mathrm{mg} / \mathrm{g}$ in a pristine biochar system, to $724.29 \mu \mathrm{g} / \mathrm{g}$ in an iron-modified biochar system, respectively [123].

Biochar controlled the loss of pesticides through a slow desorption process exemplified by spraying chlorpyrifos solutions containing micro- to nano-sized straw ash-based biochar particles on crops. Results indicated that pesticides tended to remain in soils, amended by biochar, despite washing, volatilization, and leaching actions [122], which enabled lessfrequent pesticide applications. Pesticides in biochar-amended soils were slowly released to crops, which substantially minimized the potential risk of over-dosing. 


\section{Biochar Mediated Degradation}

\subsection{Organic Carbons}

Many factors, such as biochar loadings [126] and the concentration of labile organic carbon, strongly affected $\mathrm{CO}_{2}$ emissions from soils [127]. A number of studies reported that biochar amendment in soils exhibited positive priming effects, i.e., stimulating the turnover of soil organic carbon and thus net $\mathrm{CO}_{2}$ emission [77]. However, there were a number of studies that showed negative priming effects on $\mathrm{CO}_{2}$ sequestration $[64,128]$. The biodegradation of soil organic matters was decreased when being adsorbed into the porous structure of biochar, a negative priming effect. On the other hand, biochar also enhanced $\mathrm{CO}_{2}$ mineralization in soils [129], thereby exhibiting a positive priming effect. Luo et al. (2016) noted that the degree of soil organic carbon mineralization was much lower than theoretically predicted when the applied biochar to soil ratio was at $1-3 \%$, thus a negative priming effect [64]. The adsorption of labile organic carbons onto biochar decreased the soil carbon pool. The duration of biochar application affected the priming effect also. Azeem et al. (2019) reported that biochar amendment exhibited positive priming effects (i.e., enhanced $\mathrm{CO}_{2}$ emissions) during the early phase of application, which then became negative later [4]. The reduction in $\mathrm{CO}_{2}$ emissions at a later stage might be attributed to the depletion of labile organic carbons (by positive priming at early stages) and stabilization of soil organic carbons (by biochar-induced organo-mineral interactions). Sagrilo et al. (2015) conducted a meta-analysis of a total of 46 studies on evaluating the interactions between native soil organic carbons and biochar and reported that the carbon ratio of biochar to native soil organic carbons was a practical parameter for predicting the priming effect (net $\mathrm{CO}_{2}$ emissions) with respect to biochar-amended soils [130]. When the ratio of biochar carbon and soil organic carbon was less than two, there was no significant influence of biochar application on net $\mathrm{CO}_{2}$ emissions. However, a ratio greater than two exhibited a significant increase in net $\mathrm{CO}_{2}$ emissions from biochar-amended soils.

In addition to the adsorptive removal of organic/inorganic carbons, biochar amendment could contribute to reactive removal of carbon species by chemical and/or biochemical (microbial) reactions. It must be mentioned that microbial activities are largely responsible for the decomposition of natural organic matters via a variety of enzymes. Therefore, biochar application in soil could increase soil organic matters and thus stimulate the activity of soil microorganisms. Biochar (as a pyrogenic carbonaceous matter) promotes electron transfer and generates reactive oxygen species to initiate certain bio-chemical reactions. Biochar could also serve as an electron shuttle between organic carbon species and microorganisms in soils, which facilitates biodegradation. Luo et al. (2016) observed an increase in microbial biomass carbon in biochar-amended soils, which was probably brought on by a decrease in bulk density, an increase in water-holding capacity, a cation exchange capacity, and dissolved organic carbon content after biochar application in soils [64]. Similarly, Pignatello et al. (2017) reported that biochar promoted long-range electron transfer between organic carbons and microbes, thereby facilitating local biochemical (redox) reactions [131]. Biochar contains persistent free radicals, typically $\sim 10^{18}$ unpaired spins per gram of biochar [132], which could accelerate mineralization of organic carbons.

Biochar also influences the biosynthesis of natural organic matters from $\mathrm{CO}_{2}$ in soils. Liu et al. (2019) evaluated the role of biochar application on soil properties (especially the characteristics of DOM) from a cropland Entisol and reported that biochar application in soils resulted in an increase in dissolved organic carbon (DOC) in the biochar-amended soils $(p<0.05)$ [133]. The changes of soil structure and hydraulic properties after biochar application might also play a role in the transport of DOC in different weather events, such as stormwater. 
Naturally, the addition of biochar will increase the total carbon content of the soil system. The structural carbon of biochar is stable and will be resistant to biodegradation (or microbial mineralization). However, the mineralized DOC from biochar would exhibit significant greenhouse gas emissions [134]. DOC essentially supports microbial growth Jiang et al. (2019) reported that most of the DOC in biochar-amended soil was derived from native soil organic carbon ( $>95 \%)$, regardless of the soil type [96]. Li et al. (2018) evaluated the effect of biochar amendment on changes of soil properties and reported that biochar amendment significantly decreased the heterotrophic respiration rates in soils, while increasing the autotrophic respiration rates [95]. Biochar amendment in soils would increase the flux of DOC into adjacent aquatic environments through leaching and/or runoff, thereby leading to potential impacts on the carbon cycle. Jaffe et al. (2013) estimated that leaching contributed $\sim 10 \%$ of the global riverine flux of DOC annually. In fact, the amount of soil DOC loss due to biochar amendment is dependent on the properties of both biochar (e.g., its feedstock) and soil (e.g., types of parent materials) [135]. Yang et al. (2019) reported that a high content of oxygen-containing functional groups on the biochar surface possibly enhanced the binding of large-molecular-weight organic matters, thereby effectively reducing carbon loss through leaching [43].

\subsection{Organic Nitrogen Species}

Biodegradation of organic $\mathrm{N}$ in soils is mainly carried out by $\mathrm{N}$ mineralization processes including ammonification and nitrification, in which microorganisms decompose organic $\mathrm{N}$ into inorganic forms of $\mathrm{NH}_{4}{ }^{+}$and $\mathrm{NO}_{3}{ }^{-}$. The reverse process of mineralization, i.e., immobilization, occurs frequently when $\mathrm{N}$-poor organic matter is decomposed. Previous studies showed that biochar can have positive, negative, or negligible effects on $\mathrm{N}$ mineralization, depending on feedstock type, soil type, pyrolysis temperature, heating rate, $\mathrm{pH}$, biochar chemical constituents, and microbial activities (Table 3) [10,52,60,136-138]. Ameloot et al. (2013) studied the $\mathrm{N}$ mineralization over two biochar types prepared from poultry litter and pine chips at 400 or $500{ }^{\circ} \mathrm{C}$, respectively [136]. Results demonstrated that the addition of poultry-litter-biochar enhanced $\mathrm{N}$ mineralization, while pine-chipbiochar displayed inhibitory effect. Additionally, a decrease in $\mathrm{N}$ mineralization observed in biochar samples produced at a higher pyrolysis temperature suggested lower microbial metabolic activity in the presence of biochar prepared at a high temperature [136]. Moreover, the soil organic matter content also influenced the mineralization behavior via the stimulation of microbial activity. Both $\mathrm{N}$ mineralization in poultry litter and $\mathrm{N}$ immobilization in pine-chip-biochar were more pronounced in the soils of high organic matter level (more $\mathrm{C}$ and $\mathrm{N}$ ), which was attributed to the increase in physical contact between the biochar surface and the microbial community activated by soil organic matter. 
Table 3. Characteristics of biochars produced from different feedstocks and their net mineralization.

\begin{tabular}{|c|c|c|c|c|c|c|c|c|c|c|c|c|c|}
\hline Feedstock & $\begin{array}{l}\text { Pyrolysis } \\
\text { Temp. }\left({ }^{\circ} \mathrm{C}\right)\end{array}$ & Yield (\%) & $\mathrm{pH}$ & $\mathrm{C}(\%)$ & H (\%) & $\mathrm{O}(\%)$ & N (\%) & $\mathrm{C} / \mathrm{N}$ & $\begin{array}{l}\text { BET Surface } \\
\text { Area }\left(\mathrm{m}^{2} \mathrm{~g}^{-1}\right)\end{array}$ & $\begin{array}{l}\text { Pore Volume } \\
\quad\left(\mathrm{cm}^{3} \mathrm{~g}^{-1}\right)\end{array}$ & $\begin{array}{l}\text { Soil Organic } \\
\text { Level }\end{array}$ & $\begin{array}{c}\text { Net } \\
\text { Mineralization } \\
\left.\text { (mg N g-soil }^{-1}\right)\end{array}$ & References \\
\hline \multirow{4}{*}{ Pine chip } & \multirow{2}{*}{400} & \multirow{2}{*}{-} & \multirow{2}{*}{ - } & \multirow{2}{*}{74.4} & \multirow{2}{*}{4.06} & \multirow{2}{*}{14.6} & \multirow{2}{*}{0.25} & \multirow{2}{*}{298} & \multirow{2}{*}{0.22} & \multirow{2}{*}{0.00179} & $\begin{array}{c}\text { High soil } \\
\text { organic matter }\end{array}$ & -0.0066 & \\
\hline & & & & & & & & & & & $\begin{array}{c}\text { Low soil } \\
\text { organic matter }\end{array}$ & 0.0003 & \\
\hline & \multirow{2}{*}{500} & \multirow{2}{*}{-} & \multirow{2}{*}{-} & \multirow{2}{*}{81.7} & \multirow{2}{*}{3.10} & \multirow{2}{*}{8.76} & \multirow{2}{*}{0.22} & \multirow{2}{*}{371} & \multirow{2}{*}{22.77} & \multirow{2}{*}{0.0253} & $\begin{array}{c}\text { High soil } \\
\text { organic matter }\end{array}$ & -0.0107 & \\
\hline & & & & & & & & & & & $\begin{array}{c}\text { Low soil } \\
\text { organic matter }\end{array}$ & -0.0074 & [136] \\
\hline \multirow{4}{*}{ Poultry litter } & \multirow{2}{*}{400} & \multirow{2}{*}{ - } & \multirow{2}{*}{-} & \multirow{2}{*}{41.9} & \multirow{2}{*}{2.43} & \multirow{2}{*}{16.2} & \multirow{2}{*}{4.29} & \multirow{2}{*}{10} & \multirow{2}{*}{4.85} & \multirow{2}{*}{0.0269} & $\begin{array}{c}\text { High soil } \\
\text { organic matter }\end{array}$ & 0.032 & \\
\hline & & & & & & & & & & & $\begin{array}{c}\text { Low soil } \\
\text { organic matter }\end{array}$ & 0.0257 & \\
\hline & \multirow{2}{*}{500} & \multirow{2}{*}{-} & - & 44.4 & 1.64 & 12.2 & 4.02 & 11 & 6.55 & 0.0317 & $\begin{array}{c}\text { High soil } \\
\text { organic matter }\end{array}$ & 0.0196 & \\
\hline & & & & & & & & & & & $\begin{array}{c}\text { Low soil } \\
\text { organic matter }\end{array}$ & 0.0094 & \\
\hline Wheat straw & 525 & - & 10 & 69.6 & 2.10 & 7.1 & 1.50 & 46 & 0.6 & - & Slow pyrolysis & 0.0028 & [52] \\
\hline 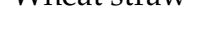 & 525 & - & 6.8 & 49.3 & 3.70 & 24.1 & 1.20 & 41 & 1.6 & - & Fast pyrolysis & -0.0206 & \\
\hline Blue mallee & 500 & - & 9.6 & 54.9 & - & - & 1.40 & 39.5 & - & - & $\begin{array}{c}\text { Dermosol + } \\
\text { Phosphorus }\end{array}$ & -0.0018 & [114] \\
\hline wood & & & & & & & & & & & $\begin{array}{c}\text { Tenosol + } \\
\text { Phosphorus }\end{array}$ & 0.0014 & \\
\hline Maize & 350 & - & 8.4 & 72.1 & - & - & 1.7 & 43 & - & - & - & $0.00207^{\mathrm{a}}$ & [138] \\
\hline & 500 & - & 9.8 & 69.1 & - & - & 1.4 & 49 & - & - & - & $0.00173^{a}$ & [138] \\
\hline Maizo & 480 & - & 8.6 & 68.1 & 1.5 & - & 0.4 & 164 & - & - & Year 1 & $0.0098^{a}$ & [139] \\
\hline & 480 & - & 8.6 & 68.1 & 1.5 & - & 0.4 & 164 & - & - & Year 2 & $0.00755^{\mathrm{a}}$ & \\
\hline
\end{tabular}


Bruun et al. (2012) studied the effect of pyrolysis on the $\mathrm{N}$ mineralization behavior of biochar made from wheat straw [52]. Slow-pyrolysis fully pyrolyzed the wheat straw, but fast-pyrolysis left a labile un-pyrolyzed biomass fraction $(8.8 \%$ carbohydrates) in the biochar. The labile $\mathrm{C}$ fraction acted as a nutrient source for soil microorganisms and resulted in $43 \% \mathrm{~N}$ immobilization during the 65 -d experiments, whereas slow-pyrolysis biochar exhibited 7\% net $\mathrm{N}$ mineralization [52]. Mia et al. (2017) conducted field $\mathrm{N}$ mineralization experiments with wood biochar in two soils, namely, Tenosol and Dermosol, and applied phosphorus as an additional treatment [114]. In Tenosol, the incorporation of biochar and phosphorus into soils improved $\mathrm{N}$ mineralization, which was attributed to the enhanced nutrient availability in Tenosol. In contrast, a biochar and phosphorus amendment decreased $\mathrm{N}$ mineralization in Dermosol due to biochar sorption or the formation of organo-mineral complexes in the soil of higher clay content [114]. In general, the $\mathrm{N}$ mineralization process was favored in soils amended by N-rich biochar or when the C:N ratio of the organic matter being decomposed was low. A threshold C: $\mathrm{N}$ ratio between 20 and 32 was reported [10].

Moreover, several studies reported that $\mathrm{N}$ mineralization and immobilization were time-dependent $[52,136,138-142]$. Slow pyrolysis-biochar, as discussed above, was capable of inducing $\mathrm{N}$ mineralization within $14 \mathrm{~d}$. However, after $65 \mathrm{~d}$, the soil mineral $\mathrm{N}$ level of treated and untreated soils were indistinguishable [52]. In addition, Nelissen et al. (2015) reported an increase in $\mathrm{N}$ mineralization after fresh biochar amendment in a maize field soil, but the degree of $\mathrm{N}$ mineralization was insignificant after one year [139]. This shortterm event was attributed to the priming effect. When fresh biochar was applied to soils, biochar might activate soil microbes to mineralize labile organic compounds on biochar and further induce co-metabolization of soil organic matters. Therefore, gross $\mathrm{N}$ mineralization was usually increased with fresh biochar, which resulted from soil-N mineralization and biochar-N mineralization [136,138,140,142]. However, $\mathrm{N}$ mineralization might decrease in the long run due to the adsorption of organic matters on the biochar surface, which became inaccessible to soil microorganisms [142]. A decrease in $\mathrm{N}$ mineralization might occur due to changes in biochar properties over time, which rendered the biochar surface inert toward the $\mathrm{N}$ cycle [139].

Figure 3 summarizes the factors affecting the adsorption, desorption, and transformation of phosphorus species in biochar-amended soil mixtures. Both abiotic (i.e., pyrolysis temperature, residence time, $\mathrm{pH}$, surface area, and co-existing cations/anions concentration) and biotic factors (i.e., type of feedstock, $\mathrm{pH}$ of soils, microbial species, and enzyme activity) would impact the fate and transport of phosphorus species via biochar. In general, high pyrolysis temperature, long pyrolysis time, presence of divalent metal ions, and animal waste feedstock would contribute to a high orthophosphate adsorption density on biochar. The transformation of biomass during pyrolysis changes the structure and further alters the properties of biochar. Low $\mathrm{pH}$, high enzyme activity, and diversified microbial population in soils would transform and mobilize phosphorus species. Glaser and Lehr conducted a meta-analysis of 108 published studies to determine the factors of biocharmediated phosphorus availability in soils in terms of biochar feedstock and carbonization temperature [21]. Results showed that biochar made from animal waste could provide more phosphorus in soils than those made from bio-waste or crop residues. Gao et al. (2019) also found in a meta-analysis of 124 published studies that a low carbon/nitrogen $(\mathrm{C} / \mathrm{N})$ ratio of biochar enhanced the phosphorus availability in soils [143]. 


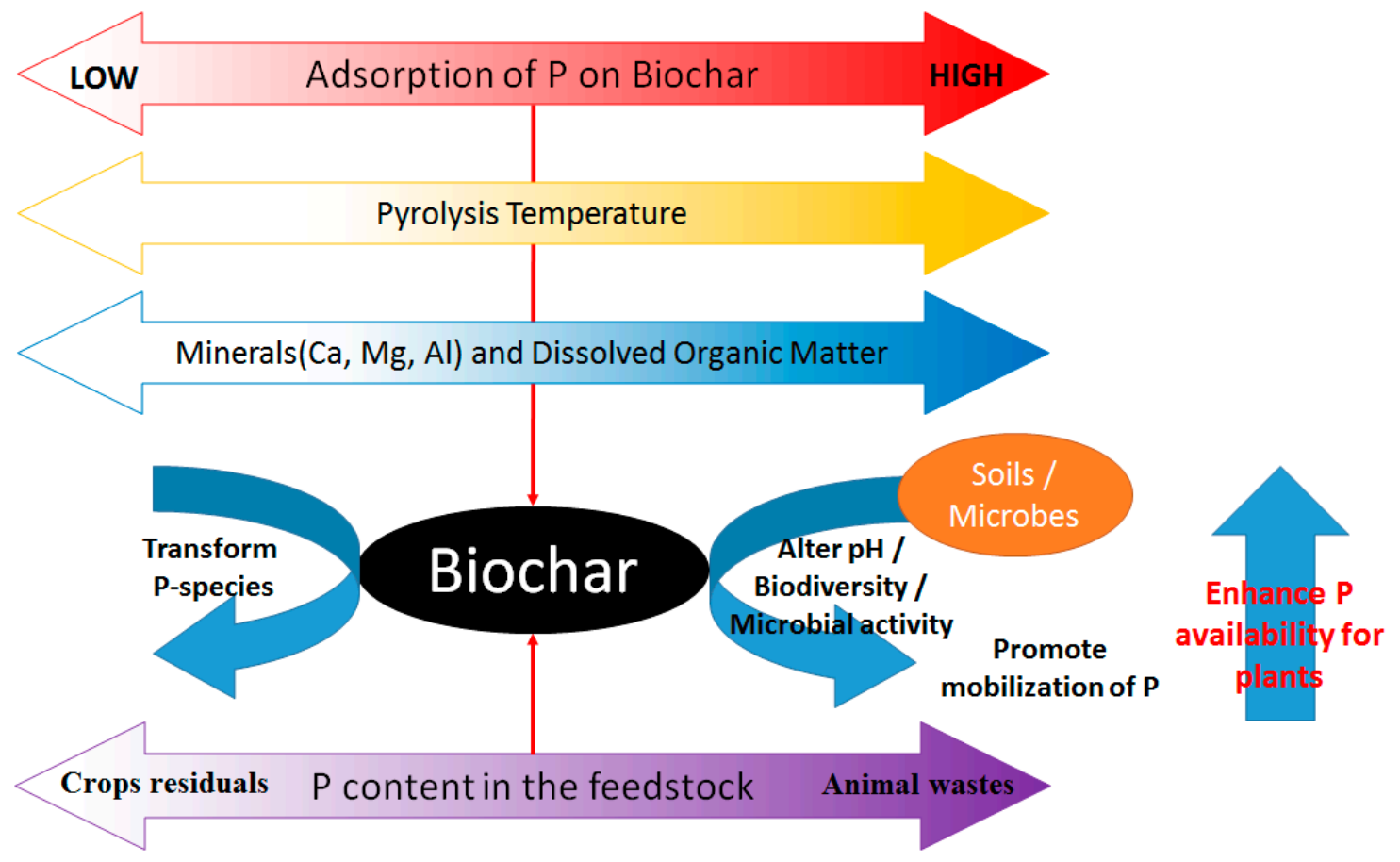

Figure 3. The role of biochar in phosphorus cycle.

\subsection{Organophosphorus Species}

Biodegradation is the major pathway to transform and decompose pesticides in soils. As mentioned above, biochar-amended soils would lower the bioavailability of pesticides. As a result, the biodegradation rate of the organophosphorus pesticide was slower in the presence of biochar than in un-amended soils [144]. For example, the half-life $\left(\mathrm{DT}_{50}\right)$ of chlorpyrifos was $21.3,23.1,32.7$ and $55.5 \mathrm{~d}$ in un-amended unsterilized soils $(0 \%)$ and in biochar-amended soils at $0.1 \%, 0.5 \%$, and $1.0 \%$ (pyrolysis at $850{ }^{\circ} \mathrm{C}$ ), respectively. The $\mathrm{DT}_{50}$ of chlorpyrifos in sterilized soils with and without biochar amendment was 3.0 to 3.3 times higher than those of unsterilized soils [124]. Overall, soil composition, biochar properties, and pesticide properties would affect the bioavailability of pesticide residues in soils. Further research is needed for a better understanding of the mechanisms of biochar-mediated organic phosphorus transformation.

Tang et al. (2017) reported that the $\mathrm{DT}_{50}$ of chlorpyrifos was 23.6, 27.9, and $29.7 \mathrm{~d}$, in un-amended soils, $1.0 \%$ biochar-amended soils, and 1.0\% iron-modified biochar soils, respectively [123]. The results showed that the diversity index increased from 7.16 to 8.80 in biochar-amended and iron-modified-biochar-amended soils, respectively, which indicated that the microbial community dynamics were affected by biochar properties. Apparently, the microbial population could be enriched in the presence of biochar. In short, the bioavailability, abundance, and structure of soil microorganisms were key factors controlling the biodegradation of pesticides in soils [123-125,145].

\section{Biochar Mediated Transport of Carbon, Nitrogen, and Phosphorus in Soil Systems}

Soil amendments, e.g., boichar and digestae, contribute toward $\mathrm{CO}_{2}$ sequestration in the biogeochemical system. A number of studies previously demonstrated that biochar exhibits positive effects on $\mathrm{CO}_{2}$ sequestration in soils due to its carbon-rich content and highly condensed aromatic structure that is resistant to long-term biodegradation. Woolf et al. (2010) estimated that the relative benefits of climate change mitigation from adding biochar to soils would be greater than that from bioenergy, with the exception of geographical regions having naturally fertile soils [2]. Similarly, Béghin-Tanneau et al. (2019) estimated that the digestate-amended soils would enhance the capacity of $\mathrm{CO}_{2}$ sequestration by a $27 \%$ reduction in $\mathrm{CO}_{2}$ emissions compared to maize silage [146]. Results of numerous 
studies also indicated that the addition of biochar to soils could substantially reduce the flux (emission) of $\mathrm{CO}_{2}[86,127]$ and $\mathrm{CH}_{4}$ [83] from soil to atmosphere. However, increasing the flux of $\mathrm{CO}_{2}$ and $\mathrm{CH}_{4}$ from the biochar-amended soil might occur if biochar loading was substantial (tonne per ha) and the duration of application was long ( years) [101,126]. In some cases, such as calcareous sandy soils [63], the contribution of biochar amendment to net $\mathrm{CO}_{2}$ flux was negligible compared to manure-amended soils. Dong et al. (2019) used the ${ }^{13} \mathrm{C}$ isotope to study the long-term effect of biochar application on the content of soil carbon and observed that biochar increased soil inorganic carbon, especially in the top 0-40 $\mathrm{cm}$ soil layers [92]. Biochar also increased the formation of pedogenic inorganic carbon, but decreased the dissolution of lithogenic inorganic carbon. For native soil organic carbon, Dong et al. (2018) reported that, after five years, biochar amendment at an application rate of 30-90 t-ha ${ }^{-1}$ decreased the content of native soil organic carbon by

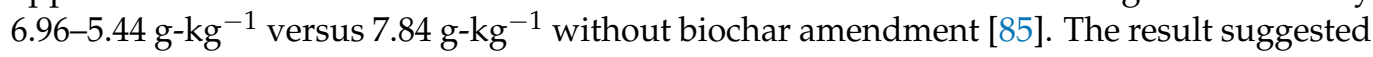
that the solubility of native soil organic carbon increased with the addition of biochar. Jiang et al. (2019) reported similar results that an increase in the solubility of native soil organic carbon led to a decrease in the $\mathrm{CO}_{2}$ sorption capability of biochar [96].

Wang and Wang (2019) demonstrated that the priming effect differed with the type of biomass feedstock and pyrolysis conditions [147]. El-Naggar et al. (2019) asserted that biochar exhibited direct and/or indirect influences on the dynamics of soil organic matters and $\mathrm{CO}_{2}$ sequestration due to its long retention time (generally on a centennial scale) in soils [65].

Standardization of biochar manufacturing and application loading in soils are also essential to the management of $\mathrm{CO}_{2}$ sequestration, soil fertility, and the nutrient cycle. El-Naggar et al. (2019) recommanded that factors, such as type of feedstock, manufacturing conditions (e.g., temperature), and pre-/post-treatment, in addition to life-cycle emissions of greenhouse gases of biocahr production, should be considered when addressing the contribution of biochar for regulating the carbon cycle [65]. Llorach-Massana et al. (2017) suggested that the transportation of both biomass feedstock for biochar production and the final biochar prodcuts should be minimized to ensure the sustainability of the manufacturing processes [148]. Moreover, the transport and retention of biochar depends on both the physicochemical properties of surrounding environmental conditions and the innate properties of biochar. The transport behaviors of biochar in natural soil can be closely related to soil humic acids that biochar in the soil rich in organic matter will possibly release into the groundwater flow [149].

Figure 4 illustrates three major process in soil $\mathrm{N}$ transport and the transformation cycle including nitrogen fixation, nitrification, and denitrification mediated by biochar. Atmospheric $\mathrm{N}_{2}$ is converted to reactive $\mathrm{N}$, such as $\mathrm{NH}_{4}{ }^{+}$, by functional marker genes of nif in nitrogen fixation (Figure 4), which renders non-reactive $\mathrm{N}_{2}$ bio-available for plants and soil organisms. Biologically mediated nitrogen fixation contributed approximately $17.2 \times 10^{7}$ tons of nitrogen to soils annually [150]. Several studies demonstrated the positive effect of biochar amendment on nitrogen fixation in soils $[18,27,149,150]$. Harter et al. (2014) conducted a microcosm study with a water-saturated soil amended with biochar and demonstrated that biochar addition significantly increased the abundance of microorganisms capable of nitrogen fixation, nif [8]. Mia et al. (2014) investigated the biological nitrogen fixation as affected by the biochar application rate and reported that biochar addition increased nitrogen fixation [151]. However, due to the complexity of biochar-soil systems, the optimal application rate was governed by biochar properties, soil nutrient status, and plant species. Therefore, the biochar application strategy is still case-specific. Biochar amendment also impacted soil characteristics, such as the oxygen content, $\mathrm{pH}, \mathrm{C}: \mathrm{N}$ ratio, and nitrogen availability that influenced the abundance and activity of nif. Moreover, the interplay among multiple parameters possibly responsible for stimulating the nif behavior of biochar-containing microcosms is noteworthy as well $[8,152]$. 


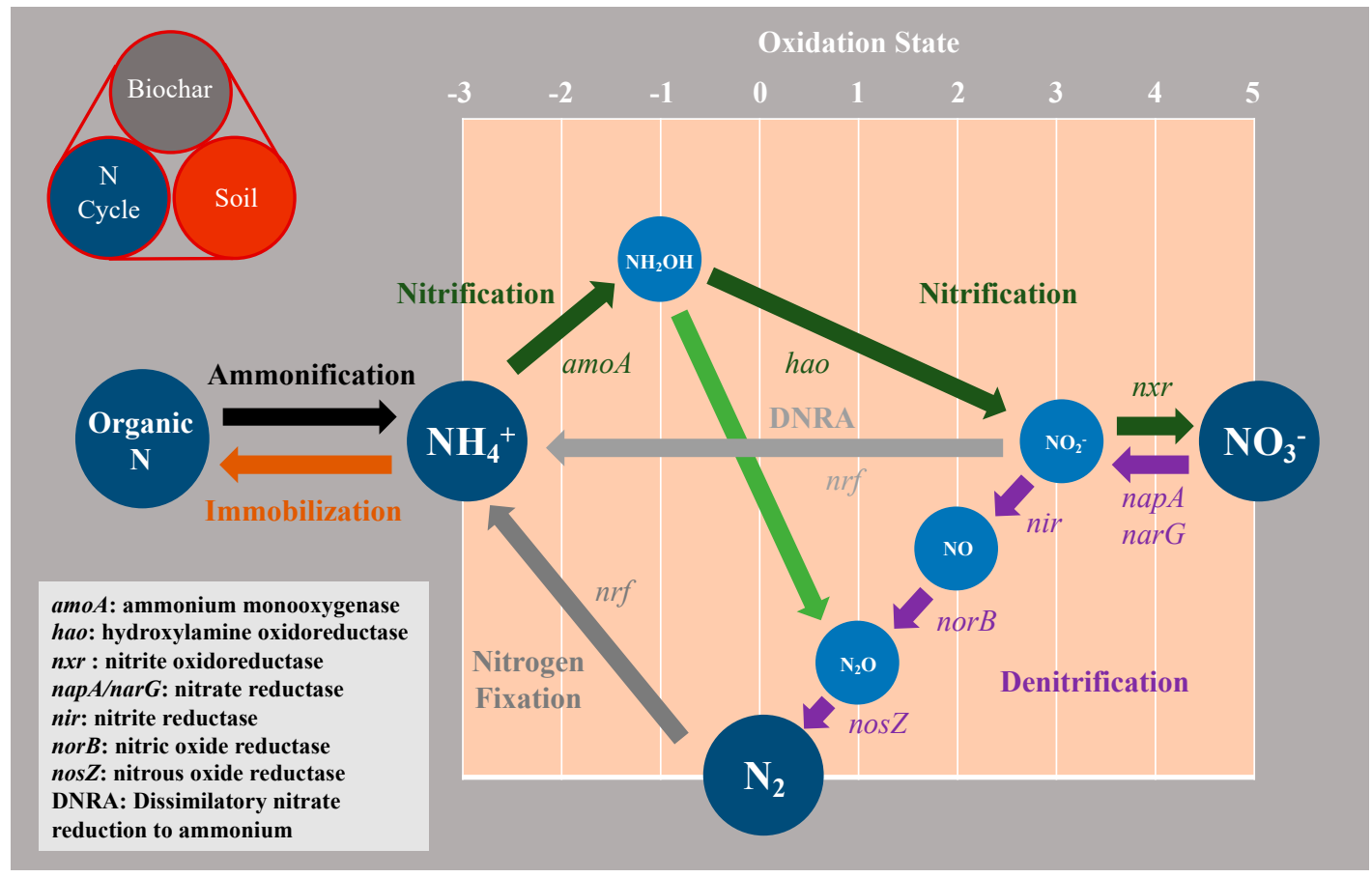

Figure 4. Schematic illustration of the nitrogen cycle with associated enzymes. Color-coded arrows indicate the different $\mathrm{N}$ transformation processes described in the main text.

Nitrification transforms $\mathrm{NH}_{4}{ }^{+}$to $\mathrm{NO}_{3}{ }^{-}$by two groups of microorganisms, i.e., ammonia oxidizers and the nitrite oxidizers (Figure 4). Since $\mathrm{NH}_{4}{ }^{+}$is the most common $\mathrm{N}$ fertilizer, rapid nitrification may increase $\mathrm{N}$ loss by $\mathrm{NO}_{3}{ }^{-}$leaching or $\mathrm{N}_{2} \mathrm{O}$ emission in the follow-up denitrification process [17]. Soil nitrification is comprised of a series of oxidization reactions: $\mathrm{NH}_{4}{ }^{+} \rightarrow \mathrm{NH}_{2} \mathrm{OH} \rightarrow \mathrm{NO}_{2}{ }^{-} \rightarrow \mathrm{NO}_{3}{ }^{-}$, in which $\mathrm{NH}_{4}{ }^{+}$to $\mathrm{NO}_{2}{ }^{-}$is known as the limiting step and is carried out by ammonia-oxidizing bacteria (AOB) with enzymes of amo and hao [10,26]. A few studies explored the possibility of using biochar amendment to weaken the nitrification rate in soils $[17,153]$. Unfortunately, in most cases, biochar amendment tended to accelerate nitrification and further increased $\mathrm{N}_{2} \mathrm{O}$ emission, which led one to question the soundness of biochar-induced alterations in the soil $\mathrm{N}$ cycle $[137,154-156]$. Wang et al. (2015) reported that organic substrates, such as phenolic compounds, in peanut shell biochar inhibited AOB activity in acidic soils and suppressed nitrification [153]. Nonetheless, the peanut shell biochar also enhanced crop growth and improved $\mathrm{N}$ bio-availability. To determine the influence of phenolic compounds on nitrification, a phenolic compound-free biochar was also applied to the same soil. Results showed that both $\mathrm{AOB}$ abundance and $\mathrm{NO}_{3}{ }^{-}$concentration increased with the amendment of phenolic compound-free biochar, which indicated enhancement of nitrification in the absence of phenolic compounds [153]. Ball et al. (2010) demonstrated that the charcoal content in acidic forest soils could influence AOB abundance and nitrification [154]. Ball et al. (2010) investigated the influence of wildfire on nitrification and reported that a 12-year-old wildfire resulted in greater charcoal content and a nitrification rate compared to sites without fire for 75 years [154]. Additionally, the field-collected charcoal from the wildfire was shown to reduce the concentration of phenolic compounds effectively and promote nitrification, suggesting that charcoal potentially increased the abundance and community diversity of AOB in the forest [154]. Several recent studies revealed that biochar amendment might decrease the efficiency of nitrification inhibitors such as dimethylpyrazole phosphate (DMPP) due to sorption. Furthermore, the DMPP sorption behavior was highly dependent on feedstock type and pyrolysis temperature $[155,156]$. Kleiblinger et al. (2018) showed that biochar pyrolyzed at $400^{\circ} \mathrm{C}$ exhibited greater DMPP sorption than that treated at $525^{\circ} \mathrm{C}$, which was attributed to an increase in hydrophobicity due to a decrease 
in the pyrolysis temperature, as evident by the positive linear relationship between the maximum sorption density and contact angle of biochar $\left(r^{2}=0.9796 ; p=0.0204\right)$ [155].

Note that nitrification is also a potential pathway for $\mathrm{N}_{2} \mathrm{O}$ formation via chemical decomposition of $\mathrm{NH}_{2} \mathrm{OH}$, an intermediate product of $\mathrm{NH}_{4}{ }^{+}$oxidation $[26,137,157]$. In the event of incomplete nitrification, $\mathrm{NH}_{2} \mathrm{OH}$ would decompose to nitrosyl radical $(\mathrm{NOH})$ instead of $\mathrm{NO}_{2}{ }^{-}$. The subsequent polymerization and hydrolysis reaction of $\mathrm{NOH}$ might result in the formation of $\mathrm{N}_{2} \mathrm{O}$ [157]. Although $\mathrm{N}_{2} \mathrm{O}$ formation might occur simultaneously through nitrification and denitrification in the same soil environment, presumably, the majority of $\mathrm{N}_{2} \mathrm{O}$ emission came from denitrification [25].

Denitrification proceeds by a stepwise reduction of $\mathrm{NO}_{3}{ }^{-}$or $\mathrm{NO}_{2}{ }^{-}$(nitrifier denitrification) to $\mathrm{N}_{2}$ via the intermediates of $\mathrm{NO}$ and $\mathrm{N}_{2} \mathrm{O}$ as illustrated in Figure 4 [158]. Denitrification is the major biological process in soils that transforms fixed $\mathrm{N}$ to the atmosphere and completes the $\mathrm{N}$ cycle. Most importantly, denitrification is the major source of $\mathrm{N}_{2} \mathrm{O}$ in many soil environments $[25,158]$, making denitrification of particular interest in the studies of mitigating $\mathrm{N}_{2} \mathrm{O}$ emission. Results of several studies on meta-analyses of biochar impact on soil $\mathrm{N}_{2} \mathrm{O}$ emission showed between 12 and $54 \%$ by microbial mediation $[15,16,26]$. The discrepancy on $\mathrm{N}_{2} \mathrm{O}$ emission mitigation by biochar amendment reveals the lack of consensus on the mechanisms of $\mathrm{N}_{2} \mathrm{O}$ emission from biochar-amended soils.

Two principle pathways lead to lower $\mathrm{N}_{2} \mathrm{O}$ formation: (i) decreasing $\mathrm{NO}_{3}{ }^{-}$availability for denitrification and (ii) facilitating the reduction of $\mathrm{N}_{2} \mathrm{O}$ to $\mathrm{N}_{2}$. The availability of $\mathrm{NO}_{3}{ }^{-}$ in soils is decreased by biochar sorption, microbial $\mathrm{N}$ immobilization, and biochar-induced inhibition of nitrification, as stated above. $\mathrm{N}_{2} \mathrm{O}$ to $\mathrm{N}_{2}$ reduction in the soil denitrification process can also be modified by biochar through manipulating the microbial activity, organic $\mathrm{C}$ content, $\mathrm{pH}$, and soil environment. Cayuela et al. (2013) demonstrated that $\mathrm{N}_{2} \mathrm{O}$ emission was highly correlated to biochar's buffer capacity instead of $\mathrm{pH}$ alone [25], which exhibited an electron shuttle effect (electron transfer from surface functional groups of biochar to soil denitrifying microorganisms) that ultimately enhanced the reduction of $\mathrm{N}_{2} \mathrm{O}$ to $\mathrm{N}_{2}[25,26,159,160]$. The electron shuttle argument was later supported by a study on the meta-analysis on the effect of the molar $\mathrm{H}: \mathrm{C}$ ratio on $\mathrm{N}_{2} \mathrm{O}$ mitigation [26]. Results showed that a lower molar $\mathrm{H}: \mathrm{C}$ ratio in biochar would bring higher surface aromaticity, enabling electron exchange and leading to greater $\mathrm{N}_{2} \mathrm{O}$ mitigation capacity. Ribas et al. (2019) investigated temporal effects of $\mathrm{N}_{2} \mathrm{O}$ emission in biochar-amended soils and observed that a high temperature during summer time favored complete denitrification to $\mathrm{N}_{2}$ and decreased $\mathrm{N}_{2} \mathrm{O}$ emission [161]. Instead of $\mathrm{pH}$, nitrogen bio-availability, or bulk soil microbial community, shifts. Ribas et al. (2019) hypothesized that the key factor was the biochar porous structure, which provided more and diversified microbial habitats in comparison to the bulk soil [161]. The abundant microsites ultimately became anoxic when the biochar was water-saturated or when oxygen was depleted inside of the biochar pores due to intensive microbial activity, especially under high summer temperature [8]. The biologically-induced anoxic conditions would promote complete denitrification using organic carbon as an electron donor, hence decreasing $\mathrm{N}_{2} \mathrm{O}$ emission [161].

Feedstock, pyrolysis temperature, and type of soil and plant cover could alter soil microbiota activity, biomass, and community structure $[18,145,162,163]$. Therefore, soil microbial abundance and C-cycle enzyme activities were significantly correlated to waterextractable organic C (WEOC) and microbial biomass C (MBC) [164], which was affected by soil physicochemical properties in terms of soil $C$ turnover and microbial growth. Song et al. (2020) proposed that the combined application of both biochar and nitrogen fertilizer led to significant increases in soil organic carbon (SOC), total nitrogen (TN), dissolved organic carbon (DOC), and total dissolved nitrogen (TDN) levels, while also enhancing the activity of C- and N-cycling enzymes in a synergistic manner [165]. The application of biochar did not significantly affect microbial biomass, but it was associated with changes in the microbial community structure in soil. Liu et al. (2014) demonstrated that biological soil crusts (biocrusts) significantly promoted the activities of soil urease, invertase, catalase, and dehydrogenase, and enhanced soil enzyme activities in revegetated areas and promoted 
soil C and N cycling and soil microbial activity [166]. Furthermore, Yang et al. (2018) reported that trampling biocrusts reduced soil microbial biomass $\mathrm{C}$ and $\mathrm{N}$, and enzyme activities, in desert ecosystems [167]. The declined soil available phosphorus (P), available $\mathrm{N}$, and total $\mathrm{N}$ and $\mathrm{P}$ may be the major factors that cause the observed reduction in soil microbial. Moreover, the affected bacterial community structure could enhance cycling and mobilization of phosphorus species in biochar-amended soils [163]. Likewise, biochar could modify microbial-mediated reactions in the soil phosphorus cycles, such as the mineralization of phosphorus [145]. For example, the microbial biomass and phosphorus content increased with an increase in biochar loading to $2 \%$ [168]. Anderson et al. (2011) found that biochar promoted the growth of phosphorus bacteria and potentially decreased plant pathogens [162]. Phosphorus species with a short chain length or poor crystal structure was formed on sewage sludge biochar pyrolyzed at $400{ }^{\circ} \mathrm{C}$ rather than $700{ }^{\circ} \mathrm{C}$ and exhibited high bioavailability for phosphate-solubilizing microorganisms, such as Pseudomonas putida. The phosphorus species on biochar could be further transformed by P. putida to orthophosphate [169]. Microbial biomass and soil enzyme activity were also important factors governing phosphorus mineralization. As large microbial population required more orthophosphate to sustain metabolic functions, whereas biochar-amended soil with high microbial biomass would exhibit high phosphorus mineralization rate [170].

Soil salinization and drought are two commonly occurring major threats to soil productivity in arable crop lands [171,172]. Salt-affected soils are generally low in N, P, and $\mathrm{K}$ due to a low input of organic matter from plant biomass and high losses of organic matter. The application of biochar in improving salt-affected soil received more attention recently [173]. It is common knowledge that salt-affected soil often shows poor physical and hydraulic properties, thereby leading to poor soil. Sun et al. (2017) indicated that biochar addition to the coastal saline soils at appropriate rates (i.e., $0.5 \%$ and $1 \%$ by weight) could reduce $\mathrm{N}$ leaching, retain soil $\mathrm{N}$, and decrease $\mathrm{NH}_{3}$ volatilization, which was beneficial to the sustainable use of saline soils [174]. Xu et al. (2016) found that biochar application decreased $\mathrm{P}$ availability in saline-sodic soil because of the sorption/precipitation of phosphate on biochar amendments, which showed that negative interactions between biochar and $\mathrm{P}$ fertilization limited the utility value of biochar application in saline-sodic soil [175]. Moreover, the application of biochar reduces salt and drought stress by increasing the water-holding capacity of soil through the modification of soil properties that improved plant growth in drought-stressed corn plants and and slowed fertilizers leaching from soils [172]. Therefore, interactions between biochar and soil that might affect the nutrient pool of salt-affected soils need further evaluation.

\section{Biochar Weathering in Soil Environment}

The properties of biochar in soils change substantially in time due to weathering [176]. Spokas (2013) studied the weathering of biochar in an agricultural field in Rosemount, MN, for four years and evaluated the effect of natural weathering on net GHG emissions [177]. The results indicated that the weathering process increased net $\mathrm{CO}_{2}$ emissions by up to tenfold, compared with fresh biochars, which reflected the increase in microbial mineralization, probably aided by the chemical oxidation of the biochar during weathering.

Despite recent progress in biochar amendment of soils, the mechanisms of mineral incorporation with biochar (i.e., organo-mineral interactions) in soils and the consequence of weathered (aged) biochar for the soil carbon cycle are not clearly elucidated yet. However, there are a few studies evalauting the adsorption capacity of pesticides in soils during the weathering of biochar. Kookana (2010) found that soil mineral compounds would cover the reactive surface of biochar with time, thereby gradually reducing the sorption capacity of biochar towared organic compounds, such as pesticides [178]. Similarly, Yang and Sheng (2003) indicated that the adsorption capacity of DOM in soils during the weathering process was decreased by 60\% [179]. Trigo et al. (2014) studied the soil-biochar interactions in a two-year field application and the relevant mechanisms of biochar-amended soil on the herbicide removal [180]. Results indicated that surface area, porosity, and aromaticity 
of weathered biochar increased with time, thereby enhancing the sorption of herbicides in biochar.

The mineral fraction of biochar and its weathering had significant implications on nutrient availability (e.g., release into the soil). Yao et al. (2010) simulated the geochemical weathering of a biochar produced from sewage sludge [181]. The weathering conditions were designed with neutral-to-alkaline systems for a period of $300 \mathrm{~h}$ in the presence of humic acid. The results showed that, during the weathering process, the $\mathrm{pH}$ of the biochar gradually decreased from 8.4 to 7.5 probably because of the loss of base cations through leaching and carbonation of the system. Substantial quantities of pottasium (9-10\%) and sulfur (20-28\%) were recovered in the weathering solutions. Furthermore, the addition of humic acid during the weathering process increased the dissolution and availability of $\mathrm{K}, \mathrm{S}$, $\mathrm{Ca}, \mathrm{Mg}$, and $\mathrm{P}$. However, the nitrogen availability $(<1.0 \%$ of the total $\mathrm{N})$ was not significantly observed because of the probable recalcitrant heterocyclic N structure. Wang et al. (2019) studied the weathering of cardboard-based biochar prepared from wood plastic composite fibers and reported that the color became darker after $1200 \mathrm{~h}$ of weathering [182]. Results of a FTIR analysis also indicated an increase in the concentration of carbonyl groups, such as conjugated ketones, carboxylic acids, esters, and g-lactones, in biochar composites, with an increase in weathering time. Kim et al. (2021) showed that the aging processes increased levels of DOM leaching and wet-dry aging accelerated DOM release and mobility most significantly [183]. Moreover, stronger acidification and long-term geochemical weathering studies of biochar in the soil environment will be able to predict the mid-term nutrient availability and the mineralogical transformation of biochar [181]. Future developments of the framework could have a quantitative assessment of biochar weathering and nutrient dynamics interactions in soil and their effects [184].

\section{Outlook}

This review highlights the role of biochar amendment in soils on the adsorption and transformation of carbon, nitrogen, and phosphorus species. Biochar as a soil amendment could improve the $\mathrm{CO}_{2}$ sequestration potential, enhance mineralization, and increase the retention of nitrogen and phosphorus nutrients in soils, thereby decreasing water pollution risk. The review also illustrates the current knowledge gaps and identifies future research needs with respect to the regulation of the carbon, nitrogen, and phosphorus chemical cycle. The benefits of biochar as a soil admendment are not always realized due to the limited knowledge regarding the relevant pathways and mechanisms. Future studies should focus on the relationship between biochar amendment and the dissolved organic carbon pool. Additionally, the emergence of advanced green processes for low-carbon biochar production could provide the prospects of developing new alternatives to maximizing the environmental benefits, especially climate change mitigation. The environmental benefits and impacts of biochar production should be critically quantified by life cycle assessments. In addition to environmental beneftis, both social and economic aspects must be considered when developing and employing biochar technologies. To augment the mitigation capacity of biochar-amended soils, long-term field studies with an emphasis on the functional mechanisms responsible for carbon retention and $\mathrm{CO}_{2}$ mitigation in soils are needed.

Early work on biochar-soil research is fragmented with results as diverse as the type of biochar and the biochar-soil systems studied. Since the publication of several metaanalyses and isotope studies, the pedagogical trend of biochar amendment has started to unify, and mechanisms responsible for regulating the $\mathrm{N}$ cycle can be identified. In general, higher pyrolysis temperature generally contributes to a larger surface area, larger porosity, and higher $\mathrm{C} / \mathrm{N}$ ratio of biochar, which will enhance adsorption of nitrogen and inhibit mineralization, reducing $\mathrm{N}$ loss in soils. Additionally, biochar is recognized as an efficient soil conditioner that stimulates microbial activity, regulates $\mathrm{N}$ transformation, and suppresses greenhouse gas emission.

To advance research on biochar for practical deployment further, the following aspects appear justified. Since the biochar surface property plays an important role in regulating 
the $\mathrm{C}, \mathrm{N}$, and P cycle, it is essential to study surface modification so as to tailor the physico-chemical and sorption properties of biochar. For example, various chemical modification methods, such as oxidation, nitrogenation, and sulfuration can effectively introduce appropriate oxygen-, nitrogen-, and sulfur-containing functional groups on biochar surface, which will enable different applications of biochar. Current surface modification techniques usually involve a strong acid/base, a high temperature, high pressure, or intensive redox reactions. The development of highly-efficient, cost-effective, and environmentally-benign surface modification methods for surface functionalization of the biochar surface is warranted. In addition to surface area and surface functional groups, controllable surface microstructure and pore structures are also significant to controlling the sorption and transformation of chemical species in soils. As an example, by incorporating a soft template with a specific structure into biochar precursors and then removing the template during pyrolysis may be a simple and reliable approach to obtain controlled structural and pore properties. Since biochar is generated from renewable resources with unique and tunable physico-chemical properties, it may be worthy of expanding its role as a soil amendment to other fields such as energy applications.

Extensive research on biochar remains active due to the low cost and versatile nature of biochar. There are abundant studies on the basic chemical composition and surface physical, chemical, and thermodynamic properties of biochar prepared from various sources. However, detailed mechanisms describing phosphorus mineralization in biochar-amended soils remain unclear due to the complexity of the interactions among biotic and abiotic factors. There are ample opportunities for advancing the biochar-mediated phosphorus cycle; for example, a holistic evaluation of nutrients speciation and impacts in biochar-amended soils, rather than a sole focus on one or two individual nutrient compounds; development of standard methods for biochar preparation and field applications; and an emphasis on fundamental structure/property/microbiota interactions. The current understanding of the phosphorus, nitrogen, or carbon cycle in biochar-amended soils is largely based on the examination of a single or two nutrient elements and biochar samples. The fundamental basis for the potential trade-off or synergic relation among these nutrients on biochar is still poorly understood. Even though some of these relationships were previously explored, much research remains to be done with regards to the molecular structural-application relationships. The underlying mechanism is seldom revealed or discussed which makes it difficult to construct a quantitative model for the design of biochar to attain optimal agricultural and environmental benefits.

Lack of a systematic understanding of procedures to scale promising biochar from the few hundred grams needed for laboratory studies to the thousands of tons needed for large field applications limits biochar deployment. Without standard methods, the results from laboratory or field studies prevent meaningful efficiency comparisons. Laboratory evaluations of biochar are often conducted with highly idealized mixtures or pot experiments, which are appropriate for mechanistic investigations. Field studies are also needed to determine the degree of biochar-induced changes in the phosphorus cycle and to link this process to crop yields. For example, the phosphorus cycle was furthered changed by both the biochar and fertilizer such as manure. In soils with manure, biochar addition reduced phosphorus availability compared with the control. In soils without manure, biochar increased phosphorus availability [24].

There is a pressing need for examining the biochar-soils-microbiota system, especially a molecular understanding of properties, such as microbial biomass, microbial community structure, phosphatase enzyme activity, toxicity, and environmental fate. Further understanding of the above processes would provide a perspective for future advances in the regulation of phosphorus cycle. Opportunities for biochar in both existing and emerging applications, together with a more quantitative understanding of the biochar-soils-biota system and with well-established methods for biochar preparation and field applications, hold great promise for utilizing biochar to control the nutrients cycle effectively. 


\section{Conclusions}

The benefits of biochar as a soil admendment are not always realized because of limited knowledge regarding the pathways and mechanisms on the fate, transport, and transformation of carbon, phosphorus, and nitrogen species in soils. This report reviews the role of biochar in regulating the carbon, phosphorus, and nitrogen cycle in biocharamended soils. Biochar as a soil amendment would sequester $\mathrm{CO}_{2}$, enhance mineralization, and increase the retention of nitrogen and phosphorus nutrients in soils, thereby decreasing water pollution potential. The present review also illustrates the current knowledge gaps and identifies the research needs for advancing biochar in future environmentally sustainable applications.

Funding: High appreciation goes to the Ministry of Science and Technology (MOST) of Taiwan (ROC) under Grants Number MOST 109-2636-M-002-013 and 106-2221-E-992-302-MY3 for the financial support. Additional support was provided by the U.S. National Science Foundation through trough NSF grant IOA 1632899 to CPH. H.K. was supported by the Korea Institute of Energy Technology Evaluation and Planning (KETEP) and the Ministry of Trade, Industry \& Energy (MOTIE) of the Republic of Korea (No. 20173010092510).

Institutional Review Board Statement: Not applicable.

Informed Consent Statement: Not applicable.

Conflicts of Interest: The authors declare no conflict of interest.

\section{References}

1. Minasny, B.; Malone, B.P.; McBratney, A.B.; Angers, D.A.; Arrouays, D.; Chambers, A.; Chaplot, V.; Chen, Z.S.; Cheng, K.; Das, B.S.; et al. Soil carbon 4 per mille. Geoderma 2017, 292, 59-86. [CrossRef]

2. Woolf, D.; Amonette, J.E.; Street-Perrott, F.A.; Lehmann, J.; Joseph, S. Sustainable biochar to mitigate global climate change. Nat. Commun. 2010, 1, 56. [CrossRef]

3. You, S.; Ok, Y.S.; Chen, S.S.; Tsang, D.C.W.; Kwon, E.E.; Lee, J.; Wang, C.H. A critical review on sustainable biochar system through gasification: Energy and environmental applications. Bioresour. Technol. 2017, 246, 242-253. [CrossRef]

4. Azeem, M.; Hayat, R.; Hussain, Q.; Ahmed, M.; Pan, G.; Ibrahim Tahir, M.; Imran, M.; Irfan, M. Biochar improves soil quality and $\mathrm{N}_{2}$-fixation and reduces net ecosystem $\mathrm{CO}_{2}$ exchange in a dry land legume-cereal cropping system. Soil Tillage Res. 2019, 186, 172-182. [CrossRef]

5. $\quad$ Oldfield, T.L.; Sikirica, N.; Mondini, C.; Lopez, G.; Kuikman, P.J.; Holden, N.M. Biochar, compost and biochar-compost blend as options to recover nutrients and sequester carbon. J. Environ. Manag. 2018, 218, 465-476. [CrossRef]

6. Bi, Y.; Cai, S.; Wang, Y.; Xia, Y.; Zhao, X.; Wang, S.; Xing, G. Assessing the viability of soil successive straw biochar amendment based on a five-year column trial with six different soils: Views from crop production, carbon sequestration and net ecosystem economic benefits. J. Environ. Manag. 2019, 245, 173-186. [CrossRef] [PubMed]

7. Paustian, K.; Lehmann, J.; Ogle, S.; Reay, D.; Robertson, G.P.; Smith, P. Climate-smart soils. Nature 2016, 532, 49-57. [CrossRef]

8. Harter, J.; Krause, H.M.; Schuettler, S.; Ruser, R.; Fromme, M.; Scholten, T.; Kappler, A.; Behrens, S. Linking $\mathrm{N}_{2} \mathrm{O}$ emissions from biochar-amended soil to the structure and function of the n-cycling microbial community. ISME J. 2014, 8, 660-674. [CrossRef]

9. Kammann, C.I.; Schmidt, H.P.; Messerschmidt, N.; Linsel, S.; Steffens, D.; Müller, C.; Stephen, J. Plant growth improvement mediated by nitrate capture in co-composted biochar. Sci. Rep. 2015, 5, 11080. [CrossRef]

10. Nguyen, T.T.N.; Xu, C.Y.; Tahmasbian, I.; Che, R.; Xu, Z.; Zhou, X.; Wallace, H.M.; Bai, S.H. Effects of biochar on soil available inorganic nitrogen: A review and meta-analysis. Geoderma 2017, 288, 79-96. [CrossRef]

11. Viglašová, E.; Galamboš, M.; Danková, Z.; Krivosudský, L.; Lengauer, C.L.; Hood-Nowotny, R.; Soja, G.; Rompel, A.; Matík, M.; Briančin, J. Production, characterization and adsorption studies of bamboo-based biochar/montmorillonite composite for nitrate removal. Waste Manag. 2018, 79, 385-394. [CrossRef] [PubMed]

12. Viglašová, E.; Galamboš, M.; Diviš, D.; Danková, Z.; Daňo, M.; Krivosudský, L.; Lengauer, C.L.; Matik, M.; Briančin, J.; Soja, G. Engineered biochar as a tool for nitrogen pollutants removal: Preparation, characterization and sorption study. Desalination Water Treat. 2020, 191, 318-331. [CrossRef]

13. Ahmad, M.; Rajapaksha, A.U.; Lim, J.E.; Zhang, M.; Bolan, N.; Mohan, D.; Vithanage, M.; Lee, S.S.; Ok, Y.S. Biochar as a sorbent for contaminant management in soil and water: A review. Chemosphere 2014, 99, 19-33. [CrossRef]

14. Bai, S.H.; Reverchon, F.; Xu, C.Y.; Xu, Z.; Blumfield, T.J.; Zhao, H.; Van Zwieten, L.; Wallace, H.M. Wood biochar increases nitrogen retention in field settings mainly through abiotic processes. Soil Biol. Biochem. 2015, 90, 232-240. [CrossRef]

15. Borchard, N.; Schirrmann, M.; Cayuela, M.L.; Kammann, C.; Wrage-Mönnig, N.; Estavillo, J.M.; Fuertes-Mendizábal, T.; Sigua, G.; Spokas, K.; Ippolito, J.A.; et al. Biochar, soil and land-use interactions that reduce nitrate leaching and $\mathrm{N}_{2} \mathrm{O}$ emissions: A meta-analysis. Sci. Total Environ. 2019, 651, 2354-2364. [CrossRef] 
16. Cayuela, M.L.; van Zwieten, L.; Singh, B.P.; Jeffery, S.; Roig, A.; Sánchez-Monedero, M.A. Biochar's role in mitigating soil nitrous oxide emissions: A review and meta-analysis. Agric. Ecosyst. Environ. 2014, 191, 5-16. [CrossRef]

17. Clough, T.J.; Condron, L.M. Biochar and the nitrogen cycle. J. Environ. Qual. 2010, 39, 1218-1223. [CrossRef] [PubMed]

18. Ducey, T.F.; Ippolito, J.A.; Cantrell, K.B.; Novak, J.M.; Lentz, R.D. Addition of activated switchgrass biochar to an aridic subsoil increases microbial nitrogen cycling gene abundances. Appl. Soil Ecol. 2013, 65, 65-72. [CrossRef]

19. Xiao, X.; Chen, B.; Chen, Z.; Zhu, L.; Schnoor, J.L. Insight into Multiple and Multilevel Structures of Biochars and Their Potential Environmental Applications: A Critical Review. Environ. Sci. Technol. 2018, 52, 5027-5047. [CrossRef] [PubMed]

20. Daňo, M.; Viglašová, E.; Galamboš, M.; Štamberg, K.; Kujan, J. Surface complexation models of pertechnetate on biochar/montmorillonite composite-Batch and dynamic sorption study. Materials 2020, 13, 3108. [CrossRef]

21. Glaser, B.; Lehr, V.I. Biochar effects on phosphorus availability in agricultural soils: A meta-analysis. Sci. Rep. 2019, 9, 9338. [CrossRef]

22. Zhao, X.; Li, D.; Kong, J.; Lin, Q. Does Biochar Addition Influence the Change Points of Soil Phosphorus Leaching? J. Integr. Agric. 2014, 13, 499-506. [CrossRef]

23. Arif, M.; Ilyas, M.; Riaz, M.; Ali, K.; Shah, K.; Ul Haq, I.; Fahad, S. Biochar improves phosphorus use efficiency of organic-inorganic fertilizers, maize-wheat productivity and soil quality in a low fertility alkaline soil. Field Crops Res. 2017, 214, 25-37. [CrossRef]

24. Biederman, L.A.; Phelps, J.; Ross, B.J.; Polzin, M.; Harpole, W.S. Biochar and manure alter few aspects of prairie development: A field test. Agric. Ecosyst. Environ. 2017, 236, 78-87. [CrossRef]

25. Cayuela, M.L.; Sanchez-Monedero, M.A.; Roig, A.; Hanley, K.; Enders, A.; Lehmann, J. Biochar and denitrification in soils: When, how much and why does biochar reduce $\mathrm{N}_{2} \mathrm{O}$ emissions? Sci. Rep. 2013, 3, 1732. [CrossRef] [PubMed]

26. Cayuela, M.L.; Jeffery, S.; van Zwieten, L. The molar H:Corg ratio of biochar is a key factor in mitigating $\mathrm{N}_{2} \mathrm{O}$ emissions from soil. Agric. Ecosyst. Environ. 2015, 202, 135-138. [CrossRef]

27. Chen, B.; Zhou, D.; Zhu, L. Transitional adsorption and partition on nonpolar and polar aromatic contaminants by biochars of pine needles with different pyrolytic temperatures. Environ. Sci. Technol. 2008, 42, 5137-5143. [CrossRef] [PubMed]

28. Wang, Z.; Guo, H.; Shen, F.; Yang, G.; Zhang, Y.; Zeng, Y.; Wang, L.; Xiao, H.; Deng, S. Biochar produced from oak sawdust by Lanthanum (La)-involved pyrolysis for adsorption of ammonium $\left(\mathrm{NH}_{4}{ }^{+}\right)$, nitrate $\left(\mathrm{NO}_{3}{ }^{-}\right)$, and phosphate $\left(\mathrm{PO}_{4}{ }^{3-}\right)$. Chemosphere 2015, 119, 646-653. [CrossRef]

29. Yang, J.; Li, H.; Zhang, D.; Wu, M.; Pan, B. Limited role of biochars in nitrogen fixation through nitrate adsorption. Sci. Total Environ. 2017, 592, 758-765. [CrossRef]

30. Dong, C.D.; Chen, C.W.; Hung, C.M. Synthesis of magnetic biochar from bamboo biomass to activate persulfate for the removal of polycyclic aromatic hydrocarbons in marine sediments. Bioresour. Technol. 2017, 245, 188-195. [CrossRef] [PubMed]

31. Dong, C.D.; Chen, C.W.; Kao, C.M.; Chien, C.C.; Hung, C.M. Wood-biochar-supported magnetite nanoparticles for remediation of PAH-contaminated estuary sediment. Catalysts 2018, 8, 73. [CrossRef]

32. Dong, C.D.; Chen, C.W.; Tsai, M.L.; Chang, J.H.; Lyu, S.Y.; Hung, C.M. Degradation of 4-nonylphenol in marine sediments by persulfate over magnetically modified biochars. Bioresour. Technol. 2019, 281, 143-148. [CrossRef] [PubMed]

33. Dong, C.D.; Chen, C.W.; Nguyen, T.B.; Huang, C.P.; Hung, C.M. Degradation of phthalate esters in marine sediments by persulfate over Fe-Ce/biochar composites. Chem. Eng. J. 2020, 384, 123301. [CrossRef]

34. Hung, C.M.; Huang, C.P.; Hsieh, S.L.; Tsai, M.L.; Chen, C.W.; Dong, C.D. Biochar derived from red algae for efficient remediation of 4-nonylphenol from marine sediments. Chemosphere 2020, 254, 126919. [CrossRef] [PubMed]

35. Hung, C.M.; Huang, C.P.; Chen, C.W.; Wu, C.H.; Lin, Y.L.; Dong, C.D. Activation of percarbonate by water treatment sludgederived biochar for the remediation of PAH-contaminated sediments. Environ. Pollut. 2020, 265, 114914. [CrossRef]

36. Hung, C.M.; Huang, C.P.; Chen, C.W.; Dong, C.D. The degradation of di-(2-ethylhexyl) phthalate, DEHP, in sediments using percarbonate activated by seaweed biochars and its effects on the benthic microbial community. J. Clean. Prod. 2021, 292, 126108. [CrossRef]

37. Hung, C.M.; Huang, C.P.; Cheng, C.W.; Chen, C.W.; Dong, C.D. Production and characterization of a high value-added seaweedderived biochar: Optimization of pyrolysis conditions and evaluation for sediment treatment. J. Anal. Appl. Pyrolysis 2021, 155, 105071. [CrossRef]

38. Haider, G.; Steffens, D.; Müller, C.; Kammann, C.I. Standard extraction methods may underestimate nitrate stocks captured by field-aged biochar. J. Environ. Qual. 2016, 45, 1196-1204. [CrossRef]

39. Pillai, M.G.; Simha, P.; Gugalia, A. Recovering urea from human urine by bio-sorption onto microwave activated carbonized coconut shells: Equilibrium, kinetics, optimization and field studies. J. Environ. Chem. Eng. 2014, 2, 46-55. [CrossRef]

40. Sanford, J.R.; Larson, R.A.; Runge, T. Nitrate sorption to biochar following chemical oxidation. Sci. Total Environ. 2019, 669, 938-947. [CrossRef]

41. Ventura, M.; Sorrenti, G.; Panzacchi, P.; George, E.; Tonon, G. Biochar reduces short-term Nitrate leaching from a horizon in an apple orchard. J. Environ. Qual. 2013, 42, 76-82. [CrossRef] [PubMed]

42. Wang, H.; Lin, K.; Hou, Z.; Richardson, B.; Gan, J. Sorption of the herbicide terbuthylazine in two New Zealand forest soils amended with biosolids and biochars. J. Soils Sediments 2009, 10, 283-289. [CrossRef]

43. Yang, X.Y.; Chang, K.H.; Kim, Y.J.; Zhang, J.; Yoo, G. Effects of different biochar amendments on carbon loss and leachate characterization from an agricultural soil. Chemosphere 2019, 226, 625-635. [CrossRef] [PubMed] 
44. Yao, Y.; Gao, B.; Zhang, M.; Inyang, M.; Zimmerman, A.R. Effect of biochar amendment on sorption and leaching of nitrate, ammonium, and phosphate in a sandy soil. Chemosphere 2012, 89, 1467-1471. [CrossRef] [PubMed]

45. Zhang, G.; Zhang, Q.; Sun, K.; Liu, X.; Zheng, W.; Zhao, Y. Sorption of simazine to corn straw biochars prepared at different pyrolytic temperatures. Environ. Pollut. 2011, 159, 2594-2601. [CrossRef]

46. Dong, C.D.; Chen, C.W.; Hung, C.M. Persulfate activation with rice-husk-based magnetic biochar for degrading PAEs in marine sediments. Environ. Sci. Pollut. Res. 2019, 26, 33781-33790. [CrossRef]

47. Hung, C.M.; Huang, C.P.; Chen, C.W.; Hsieh, S.L.; Dong, C.D. Effects of biochar on catalysis treatment of 4-nonylphenol in estuarine sediment and associated microbial community structure. Environ. Pollut. 2021, 268, 115673. [CrossRef]

48. Mohan, D.; Sarswat, A.; Ok, Y.S.; Pittman, C.U., Jr. Organic and inorganic contaminants removal from water with biochar, a renewable, low cost and sustainable adsorbent-A critical review. Bioresour. Technol. 2014, 160, 191-202. [CrossRef]

49. Solanki, A.; Boyer, T. Pharmaceutical removal in synthetic human urine using biochar. Environ. Sci. Water Res. Technol. 2017, 3, 553-565. [CrossRef]

50. Jin, Y.; Liang, X.; He, M.; Liu, Y.; Tian, G.; Shi, J. Manure biochar influence upon soil properties, phosphorus distribution and phosphatase activities: A microcosm incubation study. Chemosphere 2016, 142, 128-135. [CrossRef]

51. Pratiwi, E.P.A.; Hillary, A.K.; Fukuda, T.; Shinogi, Y. The effects of rice husk char on ammonium, nitrate and phosphate retention and leaching in loamy soil. Geoderma 2016, 277, 61-68. [CrossRef]

52. Bruun, E.W.; Ambus, P.; Egsgaard, H.; Hauggaard-Nielsen, H. Effects of slow and fast pyrolysis biochar on soil C and N turnover dynamics. Soil Biol. Biochem. 2012, 46, 73-79. [CrossRef]

53. Bargmann, I.; Martens, R.; Rillig, M.C.; Kruse, A.; Kücke, M. Hydrochar amendment promotes microbial immobilization of mineral N. J. Plant. Nutr. Soil Sci. 2014, 177, 59-67. [CrossRef]

54. Mao, J.D.; Johnson, R.L.; Lehmann, J.; Olk, D.C.; Neves, E.G.; Thompson, M.L.; Schmidt-Rohr, K. Abundant and stable char residues in soils: Implications for soil fertility and carbon sequestration. Environ. Sci. Technol. 2012, 46, 9571-9576. [CrossRef] [PubMed]

55. Conte, P.; Marsala, V.; Pasquale, C.D.; Bubici, S.; Valagussa, M.; Pozzi, A.; Alonzo, G. Nature of water-biochar interface interactions. Glob. Chang. Biol. Bioenergy 2013, 5, 116-121. [CrossRef]

56. Qian, L.; Chen, B. Interactions of aluminum with biochars and oxidized biochars: Implications for the biochar aging process. J. Agric. Food Chem. 2014, 62, 373-380. [CrossRef]

57. Uchimiya, M.; Bannon, D.I.; Wartelle, L.H. Retention of heavy metals by carboxyl functional groups of biochars in small arms range soil. J. Agric. Food Chem. 2012, 60, 1798-1809. [CrossRef]

58. Xu, R.; Zhao, A.; Yuan, J.; Jiang, J. pH buffering capacity of acid soils from tropical and subtropical regions of China as influenced by incorporation of crop straw biochars. J. Soils Sediments 2012, 12, 494-502. [CrossRef]

59. Clough, T.J.; Bertram, J.E.; Ray, J.L.; Condron, L.M.; O'Callaghan, M.; Sherlock, R.R.; Wells, N.S. Unweathered wood biochar impact on nitrous oxide emissions from a bovine-urine-amended pasture soil. Soil Sci. Soc. Am. J. 2010, 74, 852-860. [CrossRef]

60. Clough, T.; Condron, L.; Kammann, C.; Müller, C. A review of biochar and soil nitrogen dynamics. Agronomy 2013, 3, 275-293. [CrossRef]

61. Joseph, S.; Kammann, C.I.; Shepherd, J.G.; Conte, P.; Schmidt, H.; Hagemann, N.; Graber, E.R. Microstructural and associated chemical changes during the composting of a high temperature biochar: Mechanisms for nitrate, phosphate and other nutrient retention and release. Sci. Total Environ. 2018, 618, 1210-1223. [CrossRef]

62. Fang, Q.; Chen, B.; Lin, Y.; Guan, Y. Aromatic and hydrophobic surfaces of wood-derived biochar enhance perchlorate adsorption via hydrogen bonding to oxygen-containing organic groups. Environ. Sci. Technol. 2014, 48, 279-288. [CrossRef] [PubMed]

63. El-Naggar, A.H.; Usman, A.R.; Al-Omran, A.; Ok, Y.S.; Ahmad, M.; Al-Wabel, M.I. Carbon mineralization and nutrient availability in calcareous sandy soils amended with woody waste biochar. Chemosphere 2015, 138, 67-73. [CrossRef] [PubMed]

64. Luo, X.; Wang, L.; Liu, G.; Wang, X.; Wang, Z.; Zheng, H. Effects of biochar on carbon mineralization of coastal wetland soils in the Yellow River Delta, China. Ecol. Eng. 2016, 94, 329-336. [CrossRef]

65. El-Naggar, A.; El-Naggar, A.H.; Shaheen, S.M.; Sarkar, B.; Chang, S.X.; Tsang, D.C.W.; Rinklebe, J.; Ok, Y.S. Biochar compositiondependent impacts on soil nutrient release, carbon mineralization, and potential environmental risk: A review. J. Environ. Manag. 2019, 241, 458-467. [CrossRef] [PubMed]

66. Chen, G.; Wang, X.; Zhang, R. Decomposition temperature sensitivity of biochars with different stabilities affected by organic carbon fractions and soil microbes. Soil Tillage Res. 2019, 186, 322-332. [CrossRef]

67. Jung, S.; Park, Y.K.; Kwon, E.E. Strategic use of biochar for $\mathrm{CO}_{2}$ capture and sequestration. J. Co2 Util. 2019, 32, 128-139. [CrossRef]

68. Rittl, T.F.; Butterbach-Bahl, K.; Basile, C.M.; Pereira, L.A.; Alms, V.; Dannenmann, M.; Couto, E.G.; Cerri, C.E.P. Greenhouse gas emissions from soil amended with agricultural residue biochars: Effects of feedstock type, production temperature and soil moisture. Biomass Bioenergy 2018, 117, 1-9. [CrossRef]

69. Wu, M.; Han, X.; Zhong, T.; Yuan, M.; Wu, W. Soil organic carbon content affects the stability of biochar in paddy soil. Agric. Ecosyst. Environ. 2016, 223, 59-66. [CrossRef]

70. Doetterl, S.; Stevens, A.; Six, J.; Merckx, R.; Van Oost, K.; Casanova Pinto, M.; Casanova-Katny, A.; Muñoz, C.; Boudin, M.; Zagal Venegas, E.; et al. Soil carbon storage controlled by interactions between geochemistry and climate. Nat. Geosci. 2015, 8, 780. [CrossRef] 
71. Doetterl, S.; Berhe, A.A.; Nadeu, E.; Wang, Z.; Sommer, M.; Fiener, P. Erosion, deposition and soil carbon: A review of process-level controls, experimental tools and models to address C cycling in dynamic landscapes. Earth Sci. Rev. 2016, 154, 102-122. [CrossRef]

72. El-Naggar, A.; Lee, S.S.; Awad, Y.M.; Yang, X.; Ryu, C.; Rizwan, M.; Rinklebe, J.; Tsang, D.C.W.; Ok, Y.S. Influence of soil properties and feedstocks on biochar potential for carbon mineralization and improvement of infertile soils. Geoderma 2018, 332, 100-108. [CrossRef]

73. Yuan, H.Z.; Zhu, Z.K.; Wei, X.M.; Liu, S.I.; Peng, P.Q.; Gunina, A.; Shen, J.I.; Kuzyakov, Y.; Ge, T.D.; Wu, J.S.; et al. Straw and biochar strongly affect functional diversity of microbial metabolism in paddy soils. J. Integr. Agric. 2019, 18, 1474-1485. [CrossRef]

74. Dong, X.; Hao, Q.; Li, G.; Lin, Q.; Zhao, X. Contrast effect of long-term fertilization on SOC and SIC stocks and distribution in different soil particle-size fractions. J. Soils Sediments 2016, 17, 1054-1063. [CrossRef]

75. Namoi, N.; Pelster, D.; Rosenstock, T.S.; Mwangi, L.; Kamau, S.; Mutuo, P.; Barrios, E. Earthworms regulate ability of biochar to mitigate $\mathrm{CO}_{2}$ and $\mathrm{N}_{2} \mathrm{O}$ emissions from a tropical soil. Appl. Soil Ecol. 2019, 140, 57-67. [CrossRef]

76. Wiesmeier, M.; Urbanski, L.; Hobley, E.; Lang, B.; von Lützow, M.; Marin-Spiotta, E.; van Wesemael, B.; Rabot, E.; Ließ, M.; Garcia-Franco, N.; et al. Soil organic carbon storage as a key function of soils-A review of drivers and indicators at various scales. Geoderma 2019, 333, 149-162. [CrossRef]

77. Peng, X.; Tong, X.; Hao, L.; Wu, F. Applicability of biochar for limiting interrill erosion and organic carbon export of sloping cropland in a semi-arid area of China. Agric. Ecosyst. Environ. 2019, 280, 68-76. [CrossRef]

78. Gascó, G.; Paz-Ferreiro, J.; Cely, P.; Plaza, C.; Méndez, A. Influence of pig manure and its biochar on soil $\mathrm{CO}_{2}$ emissions and soil enzymes. Ecol. Eng. 2016, 95, 19-24. [CrossRef]

79. Pandit, N.R.; Mulder, J.; Hale, S.E.; Zimmerman, A.R.; Pandit, B.H.; Cornelissen, G. Multi-year double cropping biochar field trials in Nepal: Finding the optimal biochar dose through agronomic trials and cost-benefit analysis. Sci. Total Environ. 2018, 637, 1333-1341. [CrossRef]

80. Sandhu, S.S.; Ussiri, D.A.N.; Kumar, S.; Chintala, R.; Papiernik, S.K.; Malo, D.D.; Schumacher, T.E. Analyzing the impacts of three types of biochar on soil carbon fractions and physiochemical properties in a corn-soybean rotation. Chemosphere 2017, 184, 473-481. [CrossRef]

81. Butnan, S.; Deenik, J.L.; Toomsan, B.; Vityakon, P. Biochar properties affecting carbon stability in soils contrasting in texture and mineralogy. Agric. Nat. Resour. 2017, 51, 492-498. [CrossRef]

82. Hansen, V.; Müller-Stöver, D.; Munkholm, L.J.; Peltre, C.; Hauggaard-Nielsen, H.; Jensen, L.S. The effect of straw and wood gasification biochar on carbon sequestration, selected soil fertility indicators and functional groups in soil: An incubation study. Geoderma 2016, 269, 99-107. [CrossRef]

83. Wang, C.; Liu, J.; Shen, J.; Chen, D.; Li, Y.; Jiang, B.; Wu, J. Effects of biochar amendment on net greenhouse gas emissions and soil fertility in a double rice cropping system: A 4-year field experiment. Agric. Ecosyst. Environ. 2018, 262, 83-96. [CrossRef]

84. Zhang, X.; Chen, C.; Chen, X.; Tao, P.; Jin, Z.; Han, Z. Persistent effects of biochar on soil organic carbon mineralization and resistant carbon pool in upland red soil, China. Environ. Earth Sci. 2018, 77, 177. [CrossRef]

85. Dong, X.; Singh, B.P.; Li, G.; Lin, Q.; Zhao, X. Biochar application constrained native soil organic carbon accumulation from wheat residue inputs in a long-term wheat-maize cropping system. Agric. Ecosyst. Environ. 2018, 252, 200-207. [CrossRef]

86. Huang, R.; Tian, D.; Liu, J.; Lv, S.; He, X.; Gao, M. Responses of soil carbon pool and soil aggregates associated organic carbon to straw and straw-derived biochar addition in a dryland cropping mesocosm system. Agric. Ecosyst. Environ. 2018, 265, 576-586. [CrossRef]

87. Guan, S.; Liu, S.J.; Liu, R.Y.; Zhang, J.J.; Ren, J.; Cai, H.G.; Lin, X.X. Soil organic carbon associated with aggregate-size and density fractions in a Mollisol amended with charred and uncharred maize straw. J. Integr. Agric. 2019, 18, 1496-1507. [CrossRef]

88. Zhao, X.; Wang, J.; Wang, S.; Xing, G. Successive straw biochar application as a strategy to sequester carbon and improve fertility: A pot experiment with two rice/wheat rotations in paddy soil. Plant. Soil 2014, 378, 279-294. [CrossRef]

89. Munda, S.; Bhaduri, D.; Mohanty, S.; Chatterjee, D.; Tripathi, R.; Shahid, M.; Kumar, U.; Bhattacharyya, P.; Kumar, A.; Adak, T.; et al. Dynamics of soil organic carbon mineralization and $\mathrm{C}$ fractions in paddy soil on application of rice husk biochar. Biomass Bioenergy 2018, 115, 1-9. [CrossRef]

90. Ghorbani, M.; Asadi, H.; Abrishamkesh, S. Effects of rice husk biochar on selected soil properties and nitrate leaching in loamy sand and clay soil. Int. Soil Water Conserv. Res. 2019, 7, 258-265. [CrossRef]

91. Ghorbani, M.; Amirahmadi, E. Effect of rice husk Biochar (RHB) on some of chemical properties of an acidic soil and the absorption of some nutrients. J. Appl. Sci. Environ. Manag. 2018, 22, 313-317. [CrossRef]

92. Dong, X.; Singh, B.P.; Li, G.; Lin, Q.; Zhao, X. Biochar increased field soil inorganic carbon content five years after application. Soil Tillage Res. 2019, 186, 36-41. [CrossRef]

93. Jiang, L.I.; Han, G.M.; Lan, Y.; Liu, S.N.; Gao, J.P.; Yang, X.; Meng, J.; Chen, W.F. Corn cob biochar increases soil culturable bacterial abundance without enhancing their capacities in utilizing carbon sources in Biolog Eco-plates. J. Integr. Agric. 2017, 16, 713-724. [CrossRef]

94. Pei, J.; Zhuang, S.; Cui, J.; Li, J.; Li, B.; Wu, J.; Fang, C. Biochar decreased the temperature sensitivity of soil carbon decomposition in a paddy field. Agric. Ecosyst. Environ. 2017, 249, 156-164. [CrossRef]

95. Li, Y.; Li, Y.; Chang, S.X.; Yang, Y.; Fu, S.; Jiang, P.; Luo, Y.; Yang, M.; Chen, Z.; Hu, S.; et al. Biochar reduces soil heterotrophic respiration in a subtropical plantation through increasing soil organic carbon recalcitrancy and decreasing carbon-degrading microbial activity. Soil Boil. Biochem. 2018, 122, 173-185. [CrossRef] 
96. Jiang, X.; Tan, X.; Cheng, J.; Haddix, M.L.; Cotrufo, M.F. Interactions between aged biochar, fresh low molecular weight carbon and soil organic carbon after 3.5 years soil-biochar incubations. Geoderma 2019, 333, 99-107. [CrossRef]

97. Brassard, P.; Godbout, S.; Palacios, J.H.; Jeanne, T.; Hogue, R.; Dubé, P.; Limousy, L.; Raghavan, V. Effect of six engineered biochars on GHG emissions from two agricultural soils: A short-term incubation study. Geoderma 2018, 327, 73-84. [CrossRef]

98. Glaser, B.; Lehmann, J.; Zech, W. Ameliorating physical and chemical properties of highly weathered soils in the tropics with charcoal-A review. Biol. Fertil. Soils 2002, 35, 219-230. [CrossRef]

99. Lehmann, J.; da Silva, J.P., Jr.; Steiner, C.; Nehls, T.; Zech, W.; Glaser, B. Nutrient availability and leaching in an archaeological Anthrosol and a Ferralsol of the Central Amazon basin: Fertilizer, manure and charcoal amendments. Plant. Soil 2003, 249, 343-357. [CrossRef]

100. Mukherjee, A.; Zimmerman, A.R.; Harris, W. Surface chemistry variations among a series of laboratory-produced biochars. Geoderma 2011, 163, 247-255. [CrossRef]

101. Hagemann, N.; Joseph, S.; Schmidt, H.P.; Kammann, C.; Harter, J.; Borch, T.; Young, R.B.; Varga, K.; Taherymoosavi, S.; Elliott, K.W.; et al. Organic coating on biochar explains its nutrient retention and stimulation of soil fertility. Nat. Commun. 2017, 8, 1089. [CrossRef] [PubMed]

102. Mukherjee, A.; Zimmerman, A.R. Organic carbon and nutrient release from a range of laboratory-produced biochars and biochar-soil mixtures. Geoderma 2013, 193, 122-130. [CrossRef]

103. Schneider, F.; Haderlein, S.B. Potential effects of biochar on the availability of phosphorus-Mechanistic insights. Geoderma 2016, 277, 83-90. [CrossRef]

104. Li, J.; Li, B.; Huang, H.; Lv, X.; Zhao, N.; Guo, G.; Zhang, D. Removal of phosphate from aqueous solution by dolomite-modified biochar derived from urban dewatered sewage sludge. Sci. Total Environ. 2019, 687, 460-469. [CrossRef]

105. Cui, X.; Dai, X.; Khan, K.Y.; Li, T.; Yang, X.; He, Z. Removal of phosphate from aqueous solution using magnesiumalginate/chitosan modified biochar microspheres derived from Thalia dealbata. Bioresour. Technol. 2016, 218, 1123-1132. [CrossRef] [PubMed]

106. Takaya, C.A.; Fletcher, L.A.; Singh, S.; Okwuosa, U.C.; Ross, A.B. Recovery of phosphate with chemically modified biochars. J. Environ. Chem. Eng. 2016, 4, 1156-1165. [CrossRef]

107. Trazzi, P.A.; Leahy, J.J.; Hayes, M.H.B.; Kwapinski, W. Adsorption and desorption of phosphate on biochars. J. Environ. Chem. Eng. 2016, 4, 37-46. [CrossRef]

108. Zhang, H.; Chen, C.; Gray, E.M.; Boyd, S.E.; Yang, H.; Zhang, D. Roles of biochar in improving phosphorus availability in soils: A phosphate adsorbent and a source of available phosphorus. Geoderma 2016, 276, 1-6. [CrossRef]

109. Uchimiya, M. Influence of $\mathrm{pH}$, Ionic Strength, and Multidentate Ligand on the Interaction of CdII with Biochars. Acs Sustain. Chem. Eng. 2014, 2, 2019-2027. [CrossRef]

110. Karunanayake, A.G.; Navarathna, C.M.; Gunatilake, S.R.; Crowley, M.; Anderson, R.; Mohan, D.; Perez, F.; Pittman, C.U.; Mlsna, T. $\mathrm{Fe}_{3} \mathrm{O}_{4}$ Nanoparticles Dispersed on Douglas Fir Biochar for Phosphate Sorption. Acs Appl. Nano Mater. 2019, 2, 3467-3479. [CrossRef]

111. Novais, S.V.; Zenero, M.D.O.; Barreto, M.S.C.; Montes, C.R.; Cerri, C.E.P. Phosphorus removal from eutrophic water using modified biochar. Sci. Total Environ. 2018, 633, 825-835. [CrossRef] [PubMed]

112. Zheng, Y.; Wang, B.; Wester, A.E.; Chen, J.; He, F.; Chen, H.; Gao, B. Reclaiming phosphorus from secondary treated municipal wastewater with engineered biochar. Chem. Eng. J. 2019, 362, 460-468. [CrossRef]

113. Lustosa Filho, J.F.; Barbosa, C.F.; da Silva Carneiro, J.S.; Melo, L.C.A. Diffusion and phosphorus solubility of biochar-based fertilizer: Visualization, chemical assessment and availability to plants. Soil Tillage Res. 2019, 194, 104298. [CrossRef]

114. Mia, S.; Dijkstra, F.A.; Singh, B. Aging induced changes in biochar's functionality and adsorption behavior for phosphate and ammonium. Environ. Sci. Technol. 2017, 51, 8359-8367. [CrossRef]

115. Wang, Y.; Lin, Y.; Chiu, P.C.; Imhoff, P.T.; Guo, M. Phosphorus release behaviors of poultry litter biochar as a soil amendment. Sci. Total Environ. 2015, 512-513, 454-463. [CrossRef]

116. Xu, M.; Gao, P.; Yang, Z.; Su, L.; Wu, J.; Yang, G.; Zhang, X.; Ma, J.; Peng, H.; Xiao, Y. Biochar impacts on phosphorus cycling in rice ecosystem. Chemosphere 2019, 225, 311-319. [CrossRef]

117. Sun, K.; Qiu, M.; Han, L.; Jin, J.; Wang, Z.; Pan, Z.; Xing, B. Speciation of phosphorus in plant- and manure-derived biochars and its dissolution under various aqueous conditions. Sci. Total Environ. 2018, 634, 1300-1307. [CrossRef]

118. Jin, Z.; Chen, X.; Chen, C.; Tao, P.; Han, Z.; Zhang, X. Biochar impact on nitrate leaching in upland red soil, China. Environ. Earth Sci. 2016, 75, 1109. [CrossRef]

119. Khadem, A.; Raiesi, F. Response of soil alkaline phosphatase to biochar amendments: Changes in kinetic and thermodynamic characteristics. Geoderma 2019, 337, 44-54. [CrossRef]

120. Jian, X.; Uchimiya, M.; Orlov, A. Particle Size- and Crystallinity-Controlled Phosphorus Release from Biochars. Energy Fuels 2019, 33, 5343-5351. [CrossRef]

121. Uchimiya, M.; Wartelle, L.H.; Boddu, V.M. Sorption of Triazine and Organophosphorus Pesticides on Soil and Biochar. J. Agric. Food Chem. 2012, 60, 2989-2997. [CrossRef] [PubMed]

122. Cai, D.; Wang, L.; Zhang, G.; Zhang, X.; Wu, Z. Controlling pesticide loss by natural porous micro/nano composites: Straw ash-based biochar and biosilica. Acs Appl. Mater. Interfaces 2013, 5, 9212-9216. [CrossRef] 
123. Tang, X.Y.; Huang, W.D.; Guo, J.J.; Yang, Y.; Tao, R.; Feng, X. Use of Fe-impregnated biochar to efficiently sorb chlorpyrifos, reduce uptake by Allium fistulosum L., and enhance microbial community diversity. J. Agric. Food Chem. 2017, 65, 5238-5243. [CrossRef] [PubMed]

124. Yang, X.B.; Ying, G.G.; Peng, P.A.; Wang, L.; Zhao, J.L.; Zhang, L.J.; Yuan, P.; He, H.P. Influence of Biochars on Plant Uptake and Dissipation of Two Pesticides in an Agricultural Soil. J. Agric. Food Chem. 2010, 58, 7915-7921. [CrossRef]

125. Zhen, M.; Song, B.; Liu, X.; Chandankere, R.; Tang, J. Biochar-mediated regulation of greenhouse gas emission and toxicity reduction in bioremediation of organophosphorus pesticide-contaminated soils. Chin. J. Chem. Eng. 2018, 26, 2592-2600. [CrossRef]

126. Lu, X.; Li, Y.; Wang, H.; Singh, B.P.; Hu, S.; Luo, Y.; Li, J.; Xiao, Y.; Cai, X.; Li, Y. Responses of soil greenhouse gas emissions to different application rates of biochar in a subtropical Chinese chestnut plantation. Agric. Meteorol. 2019, 271, 168-179. [CrossRef]

127. Yang, X.; Meng, J.; Lan, Y.; Chen, W.; Yang, T.; Yuan, J.; Liu, S.; Han, J. Effects of maize stover and its biochar on soil CO 2 emissions and labile organic carbon fractions in Northeast China. Agric. Ecosyst. Environ. 2017, 240, 24-31. [CrossRef]

128. Wang, J.; Xiong, Z.; Kuzyakov, Y. Biochar stability in soil: Meta-analysis of decomposition and priming effects. Glob. Chang. Biol. Bioenergy 2016, 8, 512-523. [CrossRef]

129. Luo, Y.; Zang, H.; Yu, Z.; Chen, Z.; Gunina, A.; Kuzyakov, Y.; Xu, J.; Zhang, K.; Brookes, P.C. Priming effects in biochar enriched soils using a three-source-partitioning approach: ${ }^{14} \mathrm{C}$ labelling and ${ }^{13} \mathrm{C}$ natural abundance. Soil Boil. Biochem. 2017, 106, 28-35. [CrossRef]

130. Sagrilo, E.; Jeffery, S.; Hoffland, E.; Kuyper, T.W. Emission of $\mathrm{CO}_{2}$ from biochar-amended soils and implications for soil organic carbon. Glob. Chang. Biol. Bioenergy 2015, 7, 129-1304.

131. Pignatello, J.J.; Mitch, W.A.; Xu, W. Activity and Reactivity of Pyrogenic Carbonaceous Matter toward Organic Compounds. Environ. Sci. Technol. 2017, 51, 8893-8908. [CrossRef] [PubMed]

132. Zhang, C.; Zeng, G.; Huang, D.; Lai, C.; Chen, M.; Cheng, M.; Tang, W.; Tang, L.; Dong, H.; Huang, B.; et al. Biochar for environmental management: Mitigating greenhouse gas emissions, contaminant treatment, and potential negative impacts. Chem. Eng. J. 2019, 373, 902-922. [CrossRef]

133. Liu, C.; Wang, H.; Li, P.; Xian, Q.; Tang, X. Biochar's impact on dissolved organic matter (DOM) export from a cropland soil during natural rainfalls. Sci. Total. Environ. 2019, 650, 1988-1995. [CrossRef] [PubMed]

134. Meschewski, E.; Holm, N.; Sharma, B.K.; Spokas, K.; Minalt, N.; Kelly, J.J. Pyrolysis biochar has negligible effects on soil greenhouse gas production, microbial communities, plant germination, and initial seedling growth. Chemosphere 2019, 228, 565-576. [CrossRef]

135. Jaffe, R.; Ding, Y.; Niggemann, J.; Vahatalo, A.V.; Stubbins, A.; Spencer, R.G.; Campbell, J.; Dittmar, T. Global charcoal mobilization from soils via dissolution and riverine transport to the oceans. Science 2013, 340, 345-347. [CrossRef] [PubMed]

136. Ameloot, N.; Sleutel, S.; Das, K.C.; Kanagaratnam, J.; de Neve, S. Biochar amendment to soils with contrasting organic matter level: Effects on N mineralization and biological soil properties. Glob. Chang. Biol. Bioenergy 2013, 7, 135-144. [CrossRef]

137. Sánchez-García, M.; Alburquerque, J.A.; Sánchez-Monedero, M.A.; Roig, A.; Cayuela, M.L. Biochar accelerates organic matter degradation and enhances $\mathrm{N}$ mineralisation during composting of poultry manure without a relevant impact on gas emissions. Bioresour. Technol. 2015, 192, 272-279. [CrossRef]

138. Nelissen, V.; Rütting, T.; Huygens, D.; Staelens, J.; Ruysschaert, G.; Boeckx, P. Maize biochars accelerate short-term soil nitrogen dynamics in a loamy sand soil. Soil Biol. Biochem. 2012, 55, 20-27. [CrossRef]

139. Nelissen, V.; Rutting, T.; Huygens, D.; Ruysschaert, G.; Boeckx, P. Temporal evolution of biochar's impact on soil nitrogen processes-a ${ }^{15} \mathrm{~N}$ tracing study. Glob. Chang. Biol. Bioenergy 2015, 7, 635-645. [CrossRef]

140. Kuzyakov, Y.; Subbotina, I.; Chen, H.; Bogomolova, I.; Xu, X. Black carbon decomposition and incorporation into soil microbial biomass estimated by 14C labeling. Soil Biol. Biochem. 2009, 41, 210-219. [CrossRef]

141. Mia, S.; Singh, B.; Dijkstra, F.A. Aged biochar affects gross nitrogen mineralization and recovery: A $15 \mathrm{~N}$ study in two contrasting soils. Glob. Chang. Biol. Bioenergy 2017, 9, 1196-1206. [CrossRef]

142. Zimmerman, A.R.; Gao, B.; Ahn, M.Y. Positive and negative carbon mineralization priming effects among a variety of biocharamended soils. Soil Biol. Biochem. 2011, 43, 1169-1179. [CrossRef]

143. Gao, S.; DeLuca, T.H.; Cleveland, C.C. Biochar additions alter phosphorus and nitrogen availability in agricultural ecosystems: A meta-analysis. Sci. Total Environ. 2019, 654, 463-472. [CrossRef]

144. Liu, Y.; Lonappan, L.; Brar, S.K.; Yang, S. Impact of biochar amendment in agricultural soils on the sorption, desorption, and degradation of pesticides: A review. Sci. Total Environ. 2018, 645, 60-70. [CrossRef] [PubMed]

145. Gul, S.; Whalen, J.K. Biochemical cycling of nitrogen and phosphorus in biochar-amended soils. Soil Biol. Biochem. 2016, 103, 1-15. [CrossRef]

146. Béghin-Tanneau, R.; Guérin, F.; Guiresse, M.; Kleiber, D.; Scheiner, J.D. Carbon sequestration in soil amended with anaerobic digested matter. Soil Tillage Res. 2019, 192, 87-94. [CrossRef]

147. Wang, J.; Wang, S. Preparation, modification and environmental application of biochar: A review. J. Clean. Prod. 2019, $227,1002-1022$. [CrossRef]

148. Llorach-Massana, P.; Lopez-Capel, E.; Pena, J.; Rieradevall, J.; Montero, J.I.; Puy, N. Technical feasibility and carbon footprint of biochar co-production with tomato plant residue. Waste Manag. 2017, 67, 121-130. [CrossRef]

149. Chen, M.; Wang, D.; Yang, F.; Xu, X.; Xu, N.; Cao, X. Transport and retention of biochar nanoparticles in a paddy soil under environmentally-relevant solution chemistry conditions. Environ. Pollut. 2017, 230, 540-549. [CrossRef] [PubMed] 
150. Ishizuka, J. Trends in biological nitrogen fixation research and application. Plant. Soil 1992, 141, 197-209. [CrossRef]

151. Mia, S.; Van Groenigen, J.W.; Van De Voorde, T.F.J.; Oram, N.J.; Bezemer, T.M.; Mommer, L.; Jeffery, S. Biochar application rate affects biological nitrogen fixation in red clover conditional on potassium availability. Agric. Ecosyst. Environ. 2014, 191, 83-91. [CrossRef]

152. Abujabhah, I.S.; Doyle, R.B.; Bound, S.A.; Bowman, J.P. Assessment of bacterial community composition, methanotrophic and nitrogen-cycling bacteria in three soils with different biochar application rates. J. Soils Sediments 2018, 18, 148-158. [CrossRef]

153. Wang, Z.; Zong, H.; Zheng, H.; Liu, G.; Chen, L.; Xing, B. Reduced nitrification and abundance of ammonia-oxidizing bacteria in acidic soil amended with biochar. Chemosphere 2015, 138, 576-583. [CrossRef]

154. Ball, P.N.; MacKenzie, M.D.; DeLuca, T.H.; Montana, W.E.H. Wildfire and charcoal enhance nitrification and ammonium-oxidizing bacterial abundance in dry montane forest soils. J. Environ. Qual. 2010, 39, 1243-1253. [CrossRef]

155. Kleiblinger, K.M.; Zehetner, F.; Mentler, A.; Zechmeister-Boltenstern, S. Biochar application increases sorption of nitrification inhibitor 3,4-dimethylpyrazole phosphate in soil. Environ. Sci. Pollut. Res. 2018, 25, 11173-11177. [CrossRef] [PubMed]

156. Fuertes-Mendizábal, T.; Huérfano, X.; Vega-Mas, I.; Torralbo, F.; Menéndez, S.; Ippolito, J.A.; Kammann, C.; Wrage-Mönnig, N.; Cayuela, M.L.; Borchard, N.; et al. Biochar reduces the efficiency of nitrification inhibitor 3,4-dimethylpyrazole phosphate (DMPP) mitigating $\mathrm{N}_{2} \mathrm{O}$ emissions. Sci. Rep. 2019, 9, 2346. [CrossRef] [PubMed]

157. Thakur, I.S.; Medhi, K. Nitrification and denitrification processes for mitigation of nitrous oxide from waste water treatment plants for biovalorization: Challenges and opportunities. Bioresour. Technol. 2019, 282, 502-513. [CrossRef]

158. Braker, G.; Conrad, R. Diversity, structure, and size of $\mathrm{N}_{2} \mathrm{O}$ producing microbial communities in soils-what matters for their functioning? Adv. Appl. Microbiol. 2011, 75, 33-70.

159. Kappler, A.; Wuestner, M.L.; Ruecker, A.; Harter, J.; Halama, M.; Behrens, S. Biochar as an electron shuttle between bacteria and Fe(III) minerals. Environ. Sci. Technol. Lett. 2014, 1, 339-344. [CrossRef]

160. Wu, Z.S.; Xu, F.; Yang, C.; Su, X.X.; Guo, F.C.; Xu, Q.Y.; Peng, G.; He, Q.; Chen, Y. Highly efficient nitrate removal in a heterotrophic denitrification system amended with redoxactive biochar: A molecular and electrochemical mechanism. Bioresour. Technol. 2019, 275, 297-306. [CrossRef]

161. Ribas, A.; Mattana, S.; Llurba, R.; Debouk, H.; Sebastià, M.T.; Domene, X. Biochar application and summer temperatures reduce $\mathrm{N}_{2} \mathrm{O}$ and enhance $\mathrm{CH}_{4}$ emissions in a Mediterranean agroecosystem: Role of biologically-induced anoxic microsites. Sci. Total Environ. 2019, 685, 1075-1086. [CrossRef] [PubMed]

162. Anderson, C.R.; Condron, L.M.; Clough, T.J.; Fiers, M.; Stewart, A.; Hill, R.A.; Sherlock, R.R. Biochar induced soil microbial community change: Implications for biogeochemical cycling of carbon, nitrogen and phosphorus. Pedobiologia 2011, 54, 309-320. [CrossRef]

163. Schmalenberger, A.; Fox, A. Chapter Three-Bacterial Mobilization of Nutrients from Biochar-Amended Soils. Adv. Appl. Microbiol. 2016, 94, 109-159.

164. Ma, L.; Lv, X.; Cao, N.; Wang, Z.; Zhou, Z.; Meng, Y. Alterations of soil labile organic carbon fractions and biological properties under different residue-management methods with equivalent carbon input. Appl. Soil Ecol. 2021, 161, 103821. [CrossRef]

165. Song, D.; Chen, L.; Zhang, S.; Zheng, Q.; Ullah, S.; Zhou, W.; Wang, X. Combined biochar and nitrogen fertilizer change soil enzyme and microbial activities in a 2-year field trial. Eur. J. Soil Biol. 2020, 99, 103212. [CrossRef]

166. Liu, Y.; Yang, H.; Li, X.; Xing, Z. Effects of biological soil crusts on soil enzyme activities in revegetated areas of the Tengger Desert, China. Appl. Soil Ecol. 2014, 80, 6-14. [CrossRef]

167. Yang, H.; Liu, C.; Liu, Y.; Xing, Z. Impact of human trampling on biological soil crusts determined by soil microbial biomass, enzyme activities and nematode communities in a desert ecosystem. Eur. J. Soil Biol. 2018, 87, 61-71. [CrossRef]

168. Li, S.; Liang, C.; Shangguan, Z. Effects of apple branch biochar on soil C mineralization and nutrient cycling under two levels of N. Sci. Total Environ. 2017, 607-608, 109-119. [CrossRef] [PubMed]

169. Qian, T.; Yang, Q.; Jun, D.C.F.; Dong, F.; Zhou, Y. Transformation of phosphorus in sewage sludge biochar mediated by a phosphate-solubilizing microorganism. Chem. Eng. J. 2019, 359, 1573-1580. [CrossRef]

170. Masto, R.E.; Kumar, S.; Rout, T.K.; Sarkar, P.; George, J.; Ram, L.C. Biochar from water hyacinth (Eichornia crassipes) and its impact on soil biological activity. Catena 2013, 111, 64-71. [CrossRef]

171. Saifullah; Dahlawi, S.; Naeem, A.; Rengel, Z.; Naidu, R. Biochar application for the remediation of salt-affected soils: Challenges and opportunities. Sci. Total Environ. 2018, 625, 320-335. [CrossRef] [PubMed]

172. Mansoor, S.; Kour, N.; Manhas, S.; Zahid, S.; Wani, O.A.; Sharma, V.; Wijaya, L.; Alyemeni, M.N.; Alsahli, A.A.; El-Serehy, H.A.; et al. Biochar as a tool for effective management of drought and heavy metal toxicity. Chemosphere 2021, 271, 129458. [CrossRef] [PubMed]

173. Liang, J.; Li, Y.; Si, B.; Wang, Y.; Chen, X.; Wang, X.; Chen, H.; Wang, H.; Zhang, F.; Bai, Y.; et al. Optimizing biochar application to improve soil physical and hydraulic properties in saline-alkali soils. Sci. Total Environ. 2021, 771, 144802. [CrossRef] [PubMed]

174. Sun, H.; Lu, H.; Chu, L.; Shao, H.; Shi, W. Biochar applied with appropriate rates can reduce N leaching, keep N retention and not increase $\mathrm{NH}_{3}$ volatilization in a coastal saline soil. Sci. Total Environ. 2017, 575, 820-825. [CrossRef] [PubMed]

175. Xu, G.; Zhang, Y.; Sun, J.; Shao, H. Negative interactive effects between biochar and phosphorus fertilization on phosphorus availability and plant yield in saline sodic soil. Sci. Total Environ. 2016, 568, 910-915. [CrossRef]

176. Mohanty, S.K.; Boehm, A.B. Effect of weathering on mobilization of biochar particles and bacterial removal in a stormwater biofilter. Water Res. 2015, 85, 208-215. [CrossRef] 
177. Spokas, K.A. Impact of biochar field aging on laboratory greenhouse gas production potentials. Glob. Chang. Biol. Bioenergy 2013, 5, 165-176. [CrossRef]

178. Kookana, R.S. The role of biochar in modifying the environmental fate, bioavailability, and efficacy of pesticides in soils: A review. Soil Res. 2010, 48, 627-637. [CrossRef]

179. Yang, Y.; Sheng, G. Pesticide adsorptivity of aged particulate matter arising from crop residue burns. J. Agric. Food Chem. 2003, 51, 5047-5051. [CrossRef]

180. Trigo, C.; Spokas, K.A.; Cox, L.; Koskinen, W.C. Influence of soil biochar aging on sorption of the herbicides MCPA, nicosulfuron, terbuthylazine, indaziflam, and fluoroethyldiaminotriazine. J. Agric. Food Chem. 2014, 62, 10855-10860. [CrossRef]

181. Yao, F.X.; Arbestain, M.C.; Virgel, S.; Blanco, F.; Arostegui, J.; Macia-Agullo, J.A.; Macias, F. Simulated geochemical weathering of a mineral ash-rich biochar in a modified Soxhlet reactor. Chemosphere 2010, 80, 724-732. [CrossRef] [PubMed]

182. Wang, X.; Sotoudehniakarani, F.; Yu, Z.; Morrell, J.J.; Cappellazzi, J.; McDonald, A.G. Evaluation of corrugated cardboard biochar as reinforcing fiber on properties, biodegradability and weatherability of wood-plastic composites. Polym. Degrad. Stab. 2019, 168, 108955. [CrossRef]

183. Kim, H.B.; Kim, J.G.; Kim, T.; Alessi, D.S.; Baek, K. Interaction of biochar stability and abiotic aging: Influences of pyrolysis reaction medium and temperature. Chem. Eng. J. 2021, 411, 128441. [CrossRef]

184. Purakayasth, T.J.; Bera, T.; Bhaduri, D.; Sarkar, B.; Mandal, S.; Wade, P.; Kumari, S.; Biswas, S.; Menon, M.; Pathak, H.; et al. A review on biochar modulated soil condition improvements and nutrient dynamics concerning crop yields: Pathways to climate change mitigation and global food security. Chemosphere 2019, 227, 345-365. [CrossRef] 